\title{
El tocado corniforme femenino en la Baja Edad Media
}

\section{The horned female headdress in the late Middle Ages}

\author{
Amaya MedinA GonZÁLEZ \\ Universidad de Cantabria \\ Grupo de Investigación Arte y Patrimonio \\ Facultad de Filosofía y Letras. Edificio Interfacultativo \\ Avda. de los Castros, 52. 39005 - Santander \\ amayamedina23@gmail.com \\ ORCID: https://orcid.org/0000-0003-0585-0031 \\ Fecha de envío: 16/09/2021. Aceptado: 10/11/2021 \\ Referencia: Santander. Estudios de Patrimonio, 4 (2021), pp. 215-244. \\ DOI: https://doi.org/10.22429/Euc2021.sep.04.08 \\ ISSN 2605-4450 (ed. impresa) / ISSN 2605-5317 (digital)
}

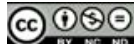

Resumen: El tocado corniforme femenino aparece representado por primera vez en la segunda mitad del siglo XIV en el monasterio de Santo Domingo de Silos. Durante el siglo XV y principios del XVI se muestra en pinturas y esculturas del norte de la Meseta en Castilla y Aragón, con extensión a Galicia y Pirineos Atlánticos (Francia). Los textos de viajeros del siglo XVI trataron de interpretar su origen y significado. Los artistas lo representaron durante la Baja Edad Media en un ámbito nobiliario y de la literatura cortesana y galante, y también en un contexto religioso ennoblecido.

Palabras clave: Vestimenta, Tocados; Tocado Corniforme; Baja Edad Media; Indumentaria Medieval; Arte Gótico; Pintura; Escultura.

\begin{abstract}
The female corniform headdress appears represented for the first time in the second half of the 14th century in the monastery of Santo Domingo de Silos. During the 15th and early 16th centuries, it was shown in paintings and sculptures from the north of the Meseta in Castile and Aragon, with extension to Galicia and the Atlantic Pyrenees (France). The texts of travelers of the 16th century tried to interpret its origin and meaning. The artists represented it during the late Middle Ages in a noble environment and in courtly and gallant literature, and also in an ennobled religious context.
\end{abstract}

Keywords: Headdresses; Corniform headdress; Middle Ages; Medieval clothing; Gothic art; Gothic Painting; Gothic Sculpture.

\section{El ORIGEN DEL TOCADO CORNIFORME}

A finales de la Edad Media surgió en el norte peninsular y en el suroeste francés un tipo de tocado femenino en forma de cuerno, compuesto por varios metros de bandas de lino o lienzo enrolladas en torno a un armazón de 
mimbre. Estos tocados indicaban el estado civil de las mujeres, casadas o viudas, mientras que las solteras eran llamadas "mozas en pelo" y llevaban la cabeza casi rapada, dejando algunas guedejas largas hacia las sienes y el flequillo, enmarcando el rostro. Los tocados variaban en su forma de unas localidades a otras y también indicaban el estatus de la portadora: a mayor riqueza, más cantidad de tela y más alto el tocado. Generalmente era de color blanco, a veces con bordados en oro y sedas y en algunos casos se empleaban colores oscuros, verdes, negros o marrones en mujeres de edad, que podrían indicar viudedad ${ }^{1}$.

Sobre su origen existen varias teorías, desde la que lo emparenta con los tocados íberos, como señala Jean Paul Tillac²; la que lo hace descender del Hennin borgoñón, capirote francés del siglo XIII, defendida por Justo Gárate Arriola y Wilhelm Giese ; y la que defiende un origen autóctono, sin relación con el Hennin, como señalan Gonzalo Manso de Zúñiga o Philippe Veyrin, basándose entre otras peculiaridades en la diferencia de su estructura, la borgoñona como un cono rígido y largo y la peninsular que tomaba forma sobre la cabeza como si fuera un turbante a modo de capirote ${ }^{4}$. Finalmente, y como derivación de la teoría anterior, se considera como un elemento de origen vasco, luego extendido a otros territorios, como indica Katherine Louise Bond ${ }^{5}$.

Para el estudio de estos tocados nos basaremos en los textos de los viajeros que en los siglos XV y XVI los mencionan por primera vez y en las imágenes pintadas y esculpidas en retablos, capiteles, monumentos funerarios, miniaturas de manuscritos y pinturas murales hasta 1520. Sobre el origen de este tocado, el cronista flamenco Laurent Vital, que acompañó a Carlos V en su llegada en 1517 a la villa de Ribadesella (Asturias), recoge una leyenda local, según la cual el rey de Castilla y el obispo de Oviedo les había ordenado

1 DUCÉRÉ, Etienne-Edouard, “La bourgeoisie bayonnaise sous l'Ancien Régime (moeurs, usages et costumes)", Bulletin de la Société des Sciences, Lettres et Arts de Pau, 18 (1889), p. 198.

2 TILLAC, Pablo (Jean Paul), "Survivance du costume ibérique chez les basques actuels". Bulletin de la Societé des Sciences, Lettres, Arts et d'Etudes de Bayonne, Bayona, s/n (3er y $4^{\circ}$ trimestre, 1924), pp. 190-206. Menciona también el tocado de los iberos CARO BAROJA, Julio, Los pueblos de España. Ensayo de etnología, Barcelona, Barna, 1946, p. 291.

3 GÁRATE ARRIOLA, Justo, "Ensayo sobre el tocado corniforme”, Revista de Estudios Vascos, 1/2 (marzo-abril 1947), pp. 237-238. GIESE, Wilhelm, Contribución al estudio del problema del antiguo tocado corniforme de las mujeres vascas: Homenaje a D. Julio de Urquijo, Hamburgo, Paul Evert, 1937, p. 11.

4 MANSO DE ZÚNIIGA, Gonzalo, “Tocados medievales”, Boletín de la Real Sociedad Bascongada de los Amigos del País, 7/4 (1951), p. 506; VEYRIN, Philippe, "A propos du turban corniforme", Boletín de la Real Sociedad Vascongada de los Amigos del País, 6/2 (1950), pp. 151-154

5 BOND, Katherine Louise, Costume Albums in Charles V's Habsburg Empire (1528-1549), Tesis Doctoral, University of Cambridge, 2017, p. 309. 


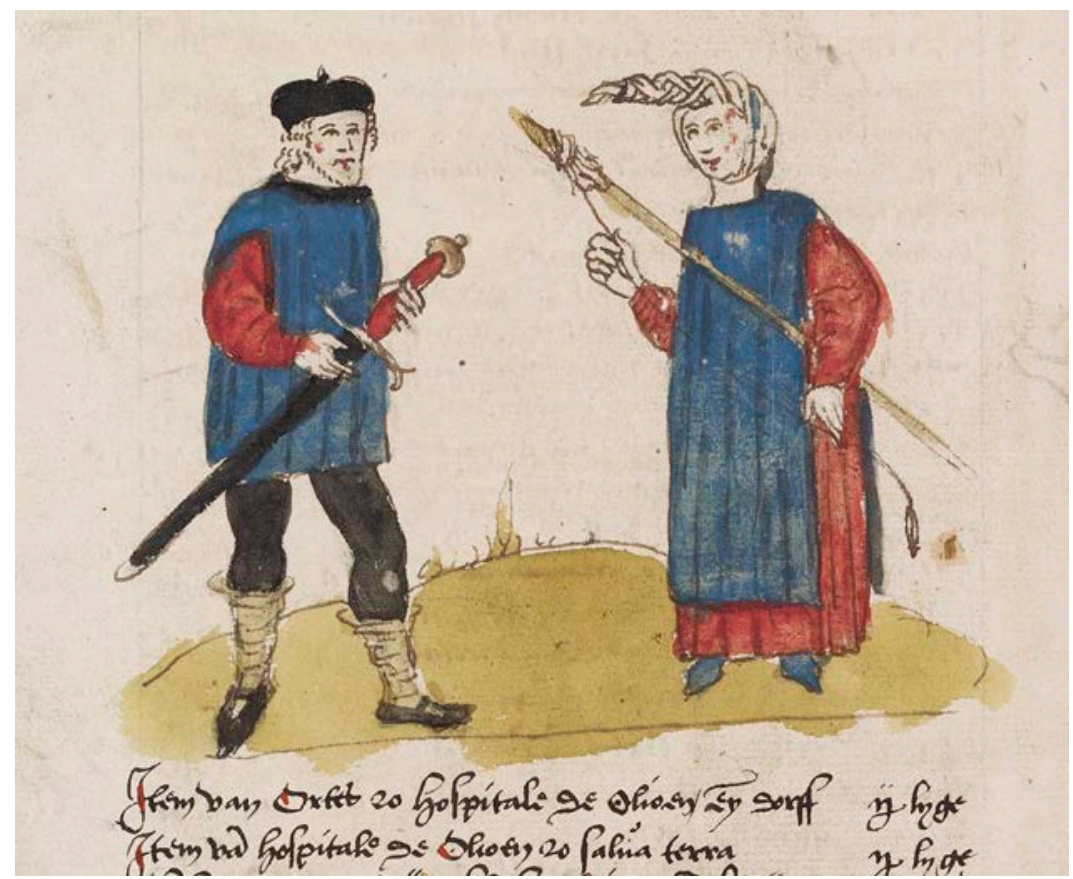

Fig. 1. Pareja de gascones en el Bearne. Die pilgerfahrt des ritters Arnold von Harff von Cöln, f. 144v. H. 1500. Photo: ( Bodleian Libraries, University of Oxford

llevarlo por la crueldad mostrada matando a sus hijos varones para que no llegaran a ser católicos, religión a la que se habían convertido sus maridos "quand le país fut redouict à la foy chrestienne" que ellas rechazaban. A consecuencia de esto fueron condenadas a llevar tales tocados "en mémoire de la cruelle mort qu'elles feirent porler á ces petits innocents masles"; y "par une maniere de penitence et pour mémoire, portent ces pénibles atours marqués au plus hault de la marque de ces dessusdicts robins, par au on cognoist que ce sont filles". El propio Laurent Vital afirma no poder asegurar la veracidad de esta explicación legendaria, y sólo se limita a mencionar que "quand le Roy arrive en ce liev, que les femmes portoient le gentil robin en leurs atours, quasi pendant sur le front" ${ }^{\prime \prime}$. Este es el único testimonio de época en el que los propios habitantes del lugar explican el origen del tocado corniforme ${ }^{7}$.

Desde finales del siglo XV aparecen crónicas de viajeros extranjeros que mencionan los tocados corniformes. Arnold von Harff (Colonia, 1471-1506) presenta en el manuscrito de su viaje de peregrinación de Colonia a Santiago

6 VITAL, Laurent, "Premier voyage de Charles-Quint en Espagne", en GACHARD, Louis Prosper y PIOT, Charles, Collection des voyages des souverains des Pays-Bas, T. III, Bruselas, F. Hayez, 1881, pp. 99-100.

7 COTERA, Gustavo, El traje en Cantabria, Santander, Cantabria, 1999, pp. 50-51. 
entre 1496 y 1499 (redactado en 1554) una imagen de una pareja de gascones vestidos a la usanza del país aunque se mencionan vistos entre Orthez y Sauveterre (Bearne, Pirineos Atlánticos, Francia) donde ella aparece portando una rueca y con tocado corniforme de color blanco compuesto de bandas de lienzo enrolladas ${ }^{8}$. (Fig. 1).

Entre 1525 y 1528 se data el viaje a España de Andrea Navagero (Venecia, 1483-Blois, 1529), quien nos dice al llegar a Guipúzcoa:

“Usan las mujeres en esta tierra un tocado muy extraño; envuelvense la cabeza en un lienzo casi a la morisca, pero no en forma de turbante, sino de capirote, con la punta doblada, haciendo una figura que semeja el pecho, el cuello y el pico de una grulla; este tocado se usa en toda Guipúzcoa, y dicen que también en Vizcaya, variando solo en que cada mujer hace que el capirote semeje una cosa diversa"

Navagero por tanto circunscribe el tocado corniforme a Guipúzcoa, donde lo ha podido contemplar, y a Vizcaya, según le informan. Estos límites están condicionados por la trayectoria de su viaje y alguna información recibida, lo que no descarta que el tocado se usara en otros lugares.

En la crónica de Laurent Vital de la llegada de Carlos I a la Península en 1517 se describen los tocados femeninos de Tazones (Asturias) de esta manera:

"Las mujeres de esas comarcas van sobriamente vestidas de paño delgado, y las más de las veces sus trajes no son más que de tela, y su atavío y adornos de cabeza son extraños, y tan altos y largos que en el tiempo pasado solían ir las damas y damiselas con sus altos tamboriles y no son tales; pero sus adornos están hechos como respaldos cubiertos por debajo de tela, bastante a la moda pagana; sus adornos son penosos y muy pesados de llevar, por la gran cantidad de tela que emplean, que les cuesta tanto como el exceso de sus vestidos. En mi opinión, no sabría comparar mejor esos adornos que como a esas aldeanas que se han cargado sobre sus cabezas ocho o diez pértigas con bandas de tela cubiertas con un trapo, o como si una mujer se hubiese plantado sobre su cabeza una gran cesta de cerezas: tan altos y anchos por encima son esos adornos"10.

\footnotetext{
8 HARFF, Arnold von, Die pilgerfahrt des ritters Arnold von Harff von Cöln, Oxford. Bodleian Library, MS, Bodleian 972, f. 144v. Publicado por GROOTE, Eberhard von, Die Pilgerfahrt der Ritters Arnold von Harff von Cöln durch Italien, Syrien, Aegypten, Arabien, Aethiopien, Nubien, Palästina, die Türkei, Frankreich und Spanien, wie er sie in den Jahren 1496-1499, Colonia, J. M. Heberle, 1860, p. 225.

9 FABIÉ, Antonio María, ed., Viajes por España, de Jorge de Einghen, del Barón de Rosmithal de Blatna, de Francisco Guicciardini y de Andrés Navajero, traducida, anotada y con una introducción por Don Antonio María Fabié, de la Academia de la Historia, Madrid, Librería de los Bibliófilos Fernando Fé, 1879, p. 347.
}

10 GARCÍA MERCADAL, José, Viajes de extranjeros por España y Portugal desde los tiempos más remotos hasta fines del siglo XVI, Salamanca, Junta de Castilla y León, 1999, v. I, p. 638-639. Publicado en francés en, "Premier voyage de Charles-Quint en Espagne, de 1517 à 1518", en 
Vital alude al origen pagano del tocado, que Navagero consideraba similar a lo morisco, en ambos casos como algo extraño a su cultura.

En 1532, el peregrino británico Andrew Boorde (h. 1490-1549) menciona que en España las principales poblaciones son Burgos y Santiago de Compostela y que las mujeres usan el tocado corniforme:

"The cheife cities and townes in Spayne is Burges \& Compostel, many of the people doth go barlegged. The maydens be polyd lyke freers; the women have silver ringes on their eres, \& coppyd thinges standeth vpon theyr hed, within ther kerchers, lyke a codpece or a gose podynge"11.

El texto señala una difusión geográfica amplia para el tocado corniforme. Otro viajero que habló sobre este tema fue Lucio Marineo Sículo, (Lucas di Marinis), capellán de Fernando el Católico y docente en la universidad de Salamanca, el cual en su obra De las cosas memorables de España, publicada en 1539, nos dice así:

"Otras trayan unos tocados de lienço de dos o tres palmos en alto como usan aún agora en las montañas y en otras partes de España. Todas estas maneras de tocados he visto yo muchas vezes entre los montañeses y vizcaínos sin poderme valer de risa"12.

En 1889 Edouard Ducéré escribía respecto a la región de Labourd y Bayona que a comienzos del siglo XVI usaban "les grants cornes", un tipo de tocado que todavía llevaban algunas ancianas, aunque prácticamente ya había desaparecido ${ }^{13}$. Ducéré cita que este tocado lo mencionaba Sébastien Moreau a comienzos del siglo XVI, cuando describe la entrada en Bayona de la reina Leonor en el mes de julio de 1530 tras conseguir la liberación de los infantes, hijos de Francisco I, que estaban como rehenes en España:

"Les dames de Bayonne estoient la plupart ès fenestres, avec leurs cornes quelles portaient sur la teste, lesquelles ils appellent 'hanons', dont les jeunes dames nouvellement mariées vouldroient bien avoir la permission de porter la drapperie, comme elles dient, qui est un couvre-chef à façon de quoquille, et aucune en portent, mais bien peu, et presque toutes le feroient si leurs marys le vouloient consentir. La principalle cause qui les en garde ce sont les vieilles dames, qui ne veullent qu'elles aient plus de liberté qu'elles. S'il plaisait au roy

GACHARD, Louis Prosper y PIOT, Charles, Collection des voyages des souverains des Pays-Bas, Bruxelles, F.Hayez, 1881, T. III, pp. 94-95.

11 FURNIVALL, Frederick James (ed.), The fyrst boke of the introduction of knowledge made by Andrew Borde, of physycke doctor. A compendyous regyment, or, A dyetary of helth made in Mountpyllier, Londres, N. Trübner \& Co., 1870, p. 199; BOND, Katherine Louise, Costume Albums..., p. 307.

12 MARINEO SICULO, Lucio, De las cosas memorables de España, Alcalá de Henares, Juan de Brocar, 1539, cap. IV, f. XXVII v.

13 DUCÉRÉ, Etienne-Edouard, "Les noms d'étoffes et de vêtements en Basque", Revue de la linguistique et de philologie comparée", 28 (15 abril 1883), p. 5. 
d'en faire comme au devant, elles seroient bien joyeuses et les porteroient volontiers; attendu que les dictes cornes est ung très or et villain habillement sentant entièrement la judayque et davantaige, qui ne cousteroit pas tant à leurs marys de les habiller"14.

Moreau habla de "cornes", "escoffions", "hannons" y "la huve" o "huvet", que describe como "cornette" elegante que llevaban las mujeres de clase media.

Como se acaba de ver, en un principio fueron descritos estos tocados por viajeros flamencos, italianos, ingleses y alemanes llegados a finales del siglo XV y principios del XVI, pero ¿qué había ocurrido previamente a ese período?

Las imágenes más antiguas que conocemos que muestran el tocado corniforme se hallan situadas en el área de la Meseta norte, de lo que podría deducirse que se trata de un modelo originado en esta zona, que después se trasladaría a la costa cantábrica. Sin embargo, la escasez de pintura y escultura bajomedieval en esta última zona puede ser la causa de que no se hallen allí representaciones de este tocado hasta el siglo XVI, por lo que conviene ser prudentes a la hora de abordar la cuestión del origen del tocado corniforme. Los ejemplos más antiguos, en Santo Domingo de Silos y Sinovas (Burgos), ambos pintados en alfarjes del sur de esta provincia, marcan un punto de partida, que durante los siglos XIV y XV tienen como centro dicha provincia y La Rioja, pero se extiende al occidente, por León, hasta Mondoñedo (Lugo); y por el oriente hasta Langa del Castillo (Zaragoza), y con el ejemplo más septentrional en una miniatura que representa a una pareja de gascones en el Bearne.

Los ejemplos del tocado corniforme de los siglos XIV y XV, y principios del XVI, son los siguientes: claustro del monasterio de Santo Domingo de Silos (h. 1384-1388); iglesia de San Nicolás de Bari en Sinovas (primer tercio siglo XV); alfarje de la colección Várez Fisa en el Museo Nacional del Prado (origen palentino, h. 1400); catedral de Oviedo (h. 1412-1441); iglesia de San Pedro en Langa del Castillo (h. 1425); catedral de Santo Domingo de la Calzada (La Rioja, h. 1440); iglesia de Nuestra Señora de la Peña en Ágreda (Soria, h. 1435-1450); castillo de Olite (Navarra, 1446); catedral de León (retablo, h. 1434-1468; y sillería del coro, 1464-1481); capilla del Condestable en la catedral de Burgos (1482-1517); dibujo de mujer gascona en el Bearne (h. 1496-1499/1554); iglesia de Santa María la Mayor de Ezcaray (La Rioja, h. 1500-1520); catedral de Mondoñedo (principios del siglo XVI); y retablo de la vida de San Blas de la iglesia de Santa María de El Collado (La Rioja, principios del siglo XVI).

14 MOREAU, Sébastien, “La Prinse et délivrance du Roy, venue de la Royne, seur aisnée de l'empereur et recouvrement des Enfants de France, 1526-1530", Archives curièuses de l'Histoire de France, 2/1 (1835), p. 440. 


\section{UN TOCADO NOBLE}

Las primeras imágenes de tocados corniformes, en la segunda mitad del siglo XIV y principios del XV, se sitúan en un contexto nobiliario (Sinovas) y de la literatura galante cortesana (Santo Domingo de Silos). Este contexto se confirma con imágenes posteriores como las de Olite (mediados del siglo XV), Montserrat (Barcelona, de origen castellano, h. 1485-1490), colección particular (procedente de León, 1434-1468), Ezcaray y Mondoñedo, estas dos últimas de principios del siglo XVI. Y en un contexto de nobleza espiritual se sitúa un capitel del claustro de la catedral de Oviedo (h. 1412-1441) y una misericordia de la sillería de la catedral de León (1464-1481). En el siglo XV tenemos los primeros indicios de que el tocado corniforme es utilizado por las clases populares: en el retablo mayor de la catedral de León (posterior a 1434), vemos al tocado corniforme en un claro contexto popular, aunque tenga un significado simbólico religioso y haya sido pintado por un artista de formación parisina; y hacia 1496-1499 el alemán Arnold von Harff veía a una gascona con tocado corniforme curvo ${ }^{15}$ entre Orthez y Sauveterre, mencionando que allí esto se utilizaba habitualmente ${ }^{16}$. Y en relación con un tocado corniforme que figura en un retablo de la vida de San Blas, del Museo de La Rioja, procedente de la iglesia de Santa María de El Collado (no inv. 302), de principios del siglo XVI, Cristina Sigüenza Pelarda, lo da como ejemplo de "moda local" y "obsoleta" perteneciente a una persona de clase social desfavorecida ${ }^{17}$, pero pensamos que este tocado tendrá una gran extensión en el norte peninsular en los siglos XVI y XVII y en gran parte en ámbitos nobles, aunque se produjo ya entonces su popularización.

Aparecen las primeras imágenes conocidas de tocados corniformes en las pinturas del alfarje del claustro de la abadía de Santo Domingo de Silos ${ }^{18}$.

15 HARFF, Arnold von, Die pilgerfahrt..., f. 144v.

16 El texto en alemán y traducción al francés en GAVEL, Henri, “Un pelerin de Saint-Jacques au Pays Basque a la fin du XVe siècle", en VV.AA., Cómo han sido y cómo son los vascos. Izakera ta jazkera. Carácter e indumentaria, San Sebastián, Auñamendi, 1975, v. II, p. 243.

17 SIGÜENZA PELARDA, Cristina, "La moda femenina a finales de la Edad Media, espejo de sensibilidad. Costumbres indumentarias de las mujeres a través de las artes plásticas del gótico en La Rioja", Berceo, 147 (2004), p. 246.

18 Un primer alfarje del claustro fue construido entre las fechas extremas de 1366 y 1384, año en el que hubo un incendio, de modo que tuvo que comenzó a reconstruirse en seguida, pues en ese mismo año, el 5 de mayo, fue expedida una Bula concediendo 40 días de indulgencia al que aportase dinero o mano de obra para su reconstrucción promovida por Gonzalo Mena y Roelas, obispo de Burgos en ese momento. Dos años más tarde, en 1386, el rey Juan I añadió una renta anual para contribuir a la obra. Y en 1388, don Pedro de Luna visitó la Abadía cuando el alfarje se estaba terminando. CONCEJO DÍEZ, María Luisa, El arte mudéjar en Burgos y su provincia, Tesis Doctoral, Universidad Complutense de Madrid, 1999, p. 734. 


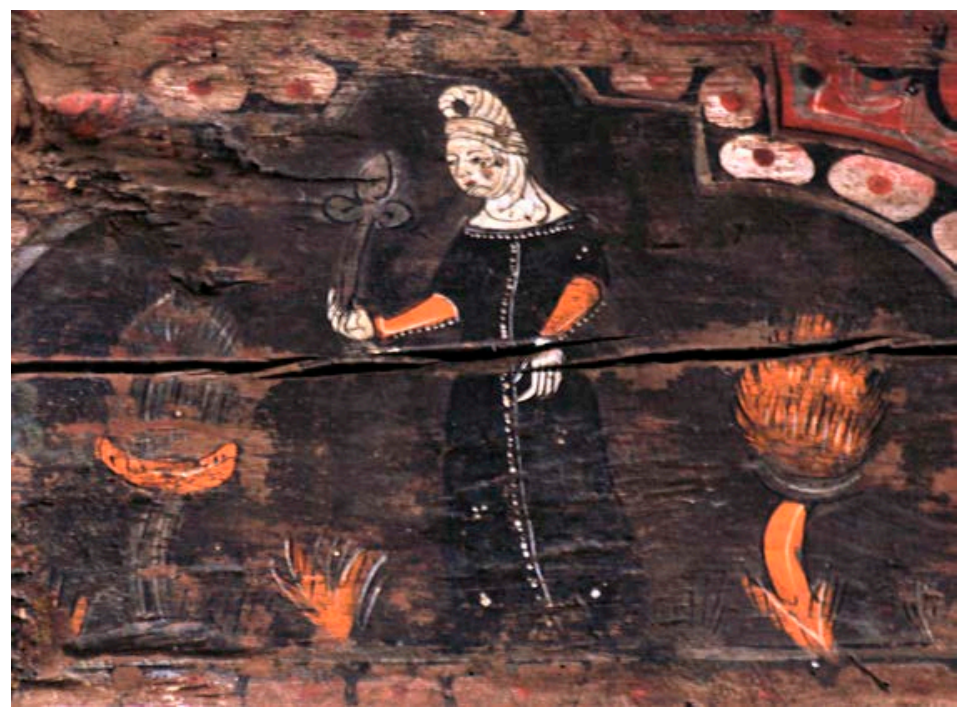

Fig. 2. Blancaflor, alfarje, claustro del monasterio de Santo Domingo de Silos. Finales del siglo XIV. Silos (Burgos)

En el alfarje meridional, labrado y pintado después de 1384, aparecen dos imágenes de mujeres con tocado corniforme, una de ellas una hilandera, y la otra con una flor en la mano. Isabel Mateo interpreta estas escenas como una representación del "mundo al revés" ${ }^{19}$ y para fray Justo Pérez de Urbel se basan en el Libro del Buen Amor del Arcipreste de Hita ${ }^{20}$. Según la interpretación de Isabel Mateo, la hilandera sería una representación de la prostitución, pero desde la Grecia clásica la imagen de una hilandera es la representación del hogar (por ej. Hestia), en el cristianismo es considerada una ocupación honesta que hasta practicaba la Virgen María ${ }^{21}$ y además el tocado corniforme será usado por las mujeres casadas. Pensamos más bien que estas imágenes están relacionadas con la literatura caballeresca y galante, como el citado Libro del Buen Amor o la narración de Flores y Blancaflor. La figura de una mujer, con el tocado corniforme, portando una flor, podría ser identificada como Blancaflor, iconografía que, sin dicho tocado, aparece también en la capilla de Santa Catalina de la catedral de Burgos (1325-1354) ${ }^{22}$, justificándose

19 MATEO GÓMEZ, Isabel, “El artesonado del Claustro del Monasterio de Silos”, en IBÁÑEZ PÉREZ, Alberto Carlos (dir.), Silos. Un milenio. Actas del Congreso Internacional sobre la abadía de Sto. Domingo de Silos, Burgos, Universidad de Burgos-Abadía de Silos, v. IV, 2003, p. 278.

20 PÉREZ DE URBEL, fray Justo, El claustro de Silos, Burgos, Institución Fernán González, 1975, p. 192; JUAN LOVERA, Carmen, "El alfarje del Buen Amor", en TORO CEBALLOS, Francisco y GODINAS, Laurette (coord.), Juan Ruiz, Arcipreste de Hita, y el Libro de buen amor. III Congreso Internacional Congreso homenaje a Jacques Joset, s/p.

21 En la Leyenda dorada se cita una carta de San Jerónimo que refiere que María realizaba en el Templo "trabajo manual que consistía en tejer". VORÁGINE, Santiago de la, La leyenda dorada, Madrid, Alianza, 1982, v. 2, p. 569.

22 SÁNCHEZ AMEIJEIRAS, Rocío, "History and Stories of Love and Conversion in 


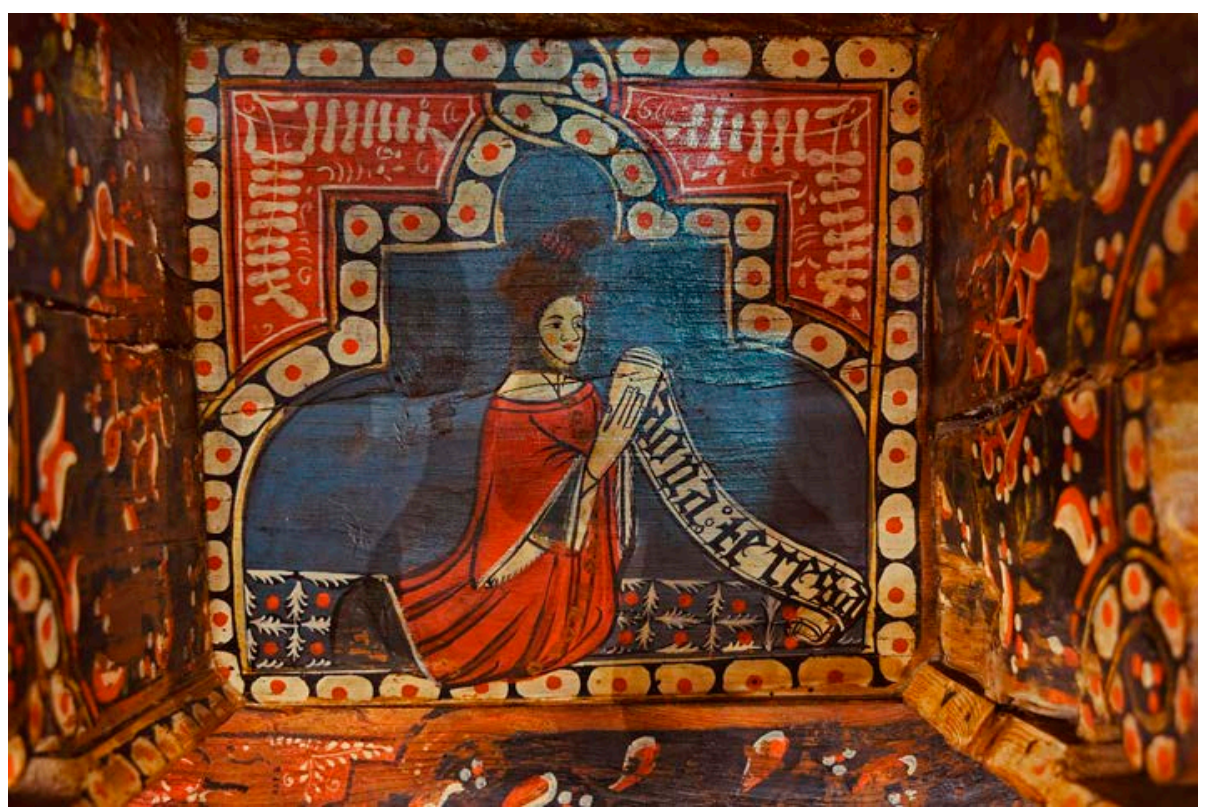

Fig. 3. Doña Teresa, alfarje de la iglesia de San Nicolás. Primer tercio del siglo XV.

Sinovas (Burgos). Foto: Rosa Tera, Batea Restauraciones

su presencia porque los protagonistas finalmente se casan y se convierten al cristianismo, con lo que la historia adquiere un carácter religioso ${ }^{23}$. (Fig. 2).

En el alfarje de la nave de la iglesia de San Nicolás en Sinovas (Fig. 3) encontramos otra imagen de mujer con tocado corniforme. Dicho artesonado se relaciona estilísticamente con el de Santo Domingo de Silos, con el que guarda gran similitud, siendo algo posterior, en torno a la segunda década del siglo $\mathrm{XV}^{24}$. La mujer mencionada está situada en el alicer del muro sur

Fourteenth-Century Burgos", Hispanic Research Journal, 13/5 (2012), p. 452. POLANCO MELERO, Carlos, “Un destello arquitectónico del siglo XIV: la capilla de Santa Catalina, antigua sala capitular de la Catedral de Burgos", Ars Bilduma, 11 (2021), p. 184.

23 Flores y Blancaflor posiblemente se base en fuentes hispánicas, mostrando la relación entre musulmanes y cristianos, pero el primer texto conocido es una versión francesa de hacia 11471150. En el siglo XIII se hicieron versiones en numerosas lenguas europeas y en castellano se imprimió en 1512, aunque la narración había sido citada en el Libro del Buen Amor, el Cancionero de Baena o el Libro de las Bienandanzas e Fortunas. BARANDA, Nieves, "Los problemas de la historia medieval de Flores y Blancaflor", DICENDA, Cuadernos de Filología Hispánica, 10 (1991-92), pp. 21-39; VAQUERO Mercedes, "Materia carolingia y motivos folklóricos en Flores y Blancaflor y el romance de Gerineldos", en ALEMANY, Rafael, MARTOS, Josep Lluís y MANZARO, Josep Miquel (eds.), Actes del X Congrés Internacional de l'Associació Hispànica de Literatura Medieval, Alicante, Institut Interuniversitari de Filologia Valenciana, 2005, v. III, pp. 1559-1574.

24 GÓMEZ GÓMEZ, Agustín, “La techumbre mudéjar de Sinovas”, Biblioteca. Estudio e 
y lleva una inscripción en una filacteria que dice "Dona Teresa", tratándose probablemente de una de las patronas que contribuyeron económicamente a la construcción de la obra del alfarje. En actitud orante en dirección al altar y portando entre sus manos la filacteria, su tocado es algo más corto y algo más romo que la anterior de Silos, y lleva una banda negra con cuarterones rojos enrollada en mitad del cuerno. Se trata, con toda seguridad del tocado de una mujer de la nobleza, no del pueblo, por sus vestiduras más lujosas:

"viste elegante 'sobretodo' de color rojo abotonado de arriba abajo con amplias mangas bajo las que se ve una saya gris. Lleva generoso escote abarquillado y se adorna con gargantilla y cuidada garlanda que termina en forma puntiaguda sobre una toca, todo ello en tonos marrones"25.

Muy similar a la pintura de los alfarjes de Silos y Sinovas es la del alfarje citado de la colección Várez Fisa, probablemente procedente de la provincia de Palencia, donde aparecen cinco mujeres danzantes así como una mujer de la Matanza de los inocentes con el tocado corniforme menos puntiagudo que los anteriormente citados.

El ambiente noble, cortesano, en que se encuentran los tocados corniformes, figura también en la crónica de Sebastian de Ilsung, natural de Augsburgo y diplomático al servicio del emperador Federico III, que viajó en peregrinación a Santiago de Compostela, pasando en 1446 por Olite (Navarra), donde estaba la corte de dicho reino. Ilsung relata la escena en el castillo de Olite, donde fue recibido por el príncipe de Viana y después por la reina Agnes de Cleves y Gastón de Foix, compañándolo de un dibujo:

"Condujome el heraldo adonde estaba la Reina, la cual se hallaba a la sazón en el terrado del castillo, rodeada de sus doncellas solazándose y tomando el fresco debajo de un gran dosel. A su lado estaba el poderoso conde de Fox, con el cual había estado yo antes. Arrodilleme delante de la Reina"26.

Este es el momento que es representado en el dibujo, donde aparece el protagonista arrodillado besando la mano de la reina, junto al conde de Foix y las damas de compañía, que lucen tocados corniformes, más altos que los

Investigación, 17 (2002), pp. 75-76. Agradecemos a Rosa Tera, de Batea Restauraciones [https:// batearestauraciones.com/], que nos haya permitido la consulta del documento, del que es autora, Memoria de: Restauración Armaduras policromadas, yeserías y retablo mayor. Iglesia San Nicolás. Sinovas-Aranda de Duero. Burgos. Expediente A2019/006488.Tomo I.- Armaduras, Junta de Castilla y León, 2019.

25 ZAPARAÍN YÁÑEZ, María José, “Con otros ojos. La promoción nobiliaria femenina en la ribera burgalesa del Duero. Siglos XVI y XVII", Biblioteca: Estudio e investigación, 28 (2013), p. 269.

26 British Library Add. no 14326, f. 1r-6r. GAYANGOS DE RIAÑO, Emilia, Viaje de España por un anónimo: 1446-8, Madrid, V. Faure, 1883, p. 27 de donde tomamos la traducción; VÁZQUEZ DE PARGA, Luis, LACARRA, José María y URÍA RIU, Juan, Las peregrinaciones a Santiago de Compostela, Madrid, Escuela de Estudios Medievales, 1948, v. 1, pp. 237-238. 


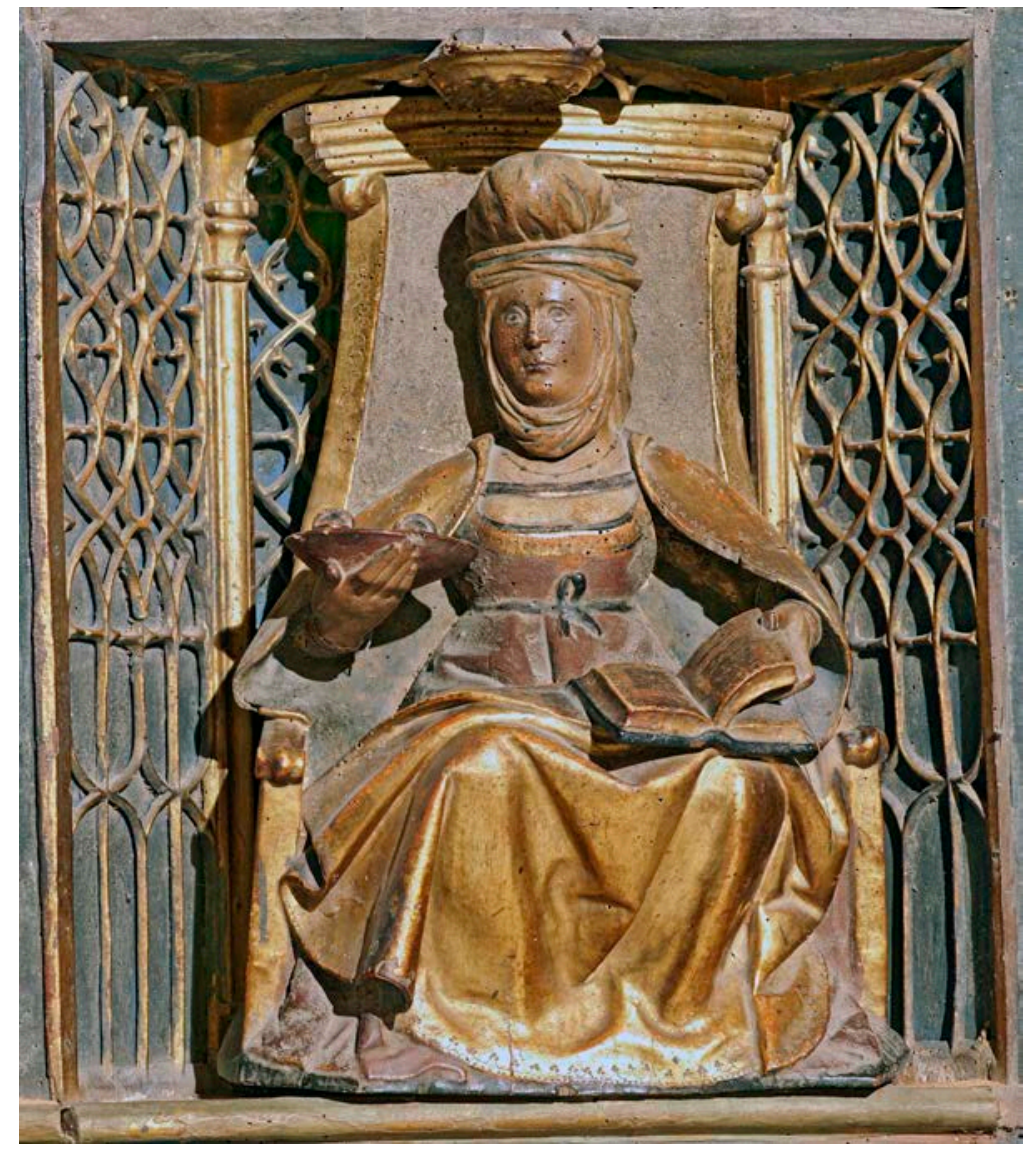

Fig. 4. Santa Lucía. 1500-1520. Retablo de San Roque, parroquia de Santa María la Mayor de Ezcaray (La Rioja). Foto: Aurelio Á. Barrón

vistos anteriormente y rematados por una borla redonda. Las damas de la reina pertenecerían a la nobleza, como era habitual (por ejemplo, "dueñas e doncellas muy fijasdalgo e muy bien vestidas" acompañan a la infanta Siringa en el Libro del caballero Zifar ${ }^{27}$ ), por lo que se confirma la idea de que a mayor riqueza, más metros de tela y más alto era el tocado.

\section{UNA NOBLEZA ESPIRITUAL}

Cuando se representa a personajes de la Historia Sagrada, el tocado corniforme es utilizado por personajes nobles. En un retablo lateral dedicado a San Roque actualmente en la iglesia parroquial de Santa María la Mayor de

27 GONZÁLEZ MUELA, Joaquín (ed.), Libro del caballero Zifar, Madrid, Editorial Castalia, 1982, p. 432. 
Ezcaray, procedente del antiguo lazareto, encontramos una imagen de Santa Lucía, representada con tocado corniforme, posiblemente obra de uno de los colaboradores del escultor Felipe Bigarny hacia 1500-152028. Santa Lucía es representada aquí como una mujer noble e intelectual, prescindiendo del símbolo habitual de los mártires, la palma ${ }^{29}$. Nació Lucía a finales del siglo III en Siracusa (Sicilia), "hija de padres nobles" como nos cuenta La leyenda dorada $a^{30}$, y recibió una educación que le permitía leer el Nuevo Testamento. Precisamente figura sentada con un libro en su mano izquierda, símbolo de sabiduría, mientras que con la derecha muestra un platillo con los ojos, que no son, como se cree habitualmente, símbolo de su martirio. Se cubre con un tocado corniforme, resaltando su carácter noble, aunque esta prenda es propia de mujeres casadas y Santa Lucía rechazó el matrimonio. El tocado que lleva es mas corto y romo que los de Silos, con un barbuquejo amplio que le tapa todo el cuello, suponemos que en el color natural de la tela. (Fig. 4).

Otro tocado corniforme figura en un conjunto de cuatro tablas atribuidas a Nicolás Francés, vendidas en subasta en Londres en julio del 2007 bajo el título de Cuatro escenas de la vida de San Esteban ${ }^{31}$. En una de ellas, un grupo de personajes ora ante el altar del Santo, y entre ellos figura una mujer con tocado corniforme blanco, y con la punta más bien roma. Para pintar esta obra, Nicolás Francés probablemente se inspiró en La leyenda dorada, en la que se recogen varios milagros de San Esteban narrados por San Agustín. En uno de ellos, el Santo cura a una familia que, por causa de una maldición pronunciada por la madre, sufría sacudidas y temblores. Por consejo de Agustín visitaron la iglesia de San Esteban en Hipona para pedirle al santo la

28 BARRÓN GARCÍA, Aurelio Á., “La obra de Felipe Bigarny en Haro: a propósito de dos imágenes inéditas del retablo de Santo Tomás de Haro (La Rioja)", Artigrama, 31 (2016), pp. 353-356.

29 CAPDEVILA, Miguel, Iconografía de Santa Lucía, Masnou (Barcelona), Laboratorios del Norte de España, 1949. Como figura sedente, con el platillo portando los ojos en una mano y el libro en la otra existe una pintura de Santa Lucía de la predela de un retablo, en el Museo de Huesca (no de inv. 00017) atribuida al círculo de Bartolomé Bermejo, por tanto de la segunda mitad del siglo XV; TORMO MONZÓ, Elías, “La pintura aragonesa cuatrocentista y la retrospectiva de la exposición de Zaragoza en general", Boletín de la Sociedad Española de Excursiones, 17 (1909), pp. 130-132; POST, Chandler Rathfon, A History of Spanish painting, v. VIII, The Aragonese school in the Late Middle Ages, Cambridge Mass., Harvard University Press, 1941, pp. 139-141.

30 VORÁGINE, Santiago de la, La leyenda dorada..., v. 1, p. 44. En latín, "Siracussana nobili genere", Leyenda áurea, manuscrito procedente del monasterio de Santes Creus. Ms. 38 de la Biblioteca Pública del Estado en Tarragona.

31 Pertenece actualmente a un coleccionista particular: https://www.sothebys.com/en/auctions/ecatalogue/2007/old-master-paintings-day-107032/lot.175.html . POST, Chandler Rathfon, A History of Spanish painting, Cambridge, Mass., Harvard University Press, 1938, v. VII, part II, p. 827. 
curación, y en la noche de Pascua, "estando el templo lleno de fieles, Pablo, abriéndose paso entre la multitud se acercó al altar, se prosternó en el suelo y comenzó a orar mientras el numeroso gentío que asistía a los oficios le miraba expectante", y de resultas de lo cual quedó curado ${ }^{32}$. En efecto, la tabla muestra a los fieles llenando la iglesia, con Pablo en primer plano, arrodillado frente al altar de San Esteban. Allí aparecen, entre los fieles, varios que portan la vara de peregrinos, correspondiendo a los miembros de esta familia que "huyeron de casa y de la ciudad y se fueron por el mundo adelante", hasta que se produjo dicho milagro en la iglesia. Entre estos "peregrinos" se halla la mujer del tocado corniforme, la citada madre, descrita en La leyenda dorada como "una noble matrona, viuda".

La representación de "matronas" se encuentra también en la tabla del Nacimiento de la Virgen pintada por Pedro Berruguete hacia 1485-1490 y conservada actualmente en el museo de la abadía de Montserrat ${ }^{33}$. Es de suponer que su origen es castellano (Ávila, Palencia o Burgos). Se representa a Santa Ana en el lecho, dando a luz a María, acompañada de tres sirvientas en el interior de una habitación, y en su pórtico exterior se hallan cuatro mujeres que acuden a visitar y prestar homenaje a la recién nacida, una de las cuales porta un tocado corniforme blanco vuelto hacia adelante y con la punta roma. Estas cuatro mujeres se diferencian de las criadas, adoptando un porte noble, que certificarían el nacimiento de María. Una vez más, vemos que el tocado corniforme es portado por mujeres nobles. La presencia de estas mujeres no consta ni en los Evangelios canónicos ni en los apócrifos (Libro sobre la Natividad de María), ni tampoco en La leyenda dorada, pero es habitual en la pintura, siempre portando ricos trajes y aspecto de nobleza, y ellas deben

32 VORÁGINE, Santiago de la, La leyenda dorada..., v. 1, p. 64.

33 Perteneció a un retablo de grandes dimensiones, a juzgar por el tamaño de la tabla (144 x $111 \mathrm{~cm}$.), de localización original indeterminada. Forma conjunto con otras dos tablas, la $\mathrm{La}$ Visitación y La muerte de la Virgen. Salió esta tabla al comercio de arte el 9 de diciembre de 1925 en American Art Galleries de Nueva York, procedente de la colección de Raimundo Ruiz, pero volvió a Madrid al no ser vendida. Tras de ser expuesta en el Pabellón de Arte Hispánico de la Exposición Universal de Barcelona de 1929, fue adquirida en 1948 por la abadía de Montserrat, en cuyo Museo se encuentra actualmente. LAÍNEZ ALCALÁ, Rafael, Pedro Berruguete, pintor de Castilla, Madrid, Espasa Calpe, 1935, pp. 60-62; POST, Chandler Rathfon, A History of Spanish painting, v. IX, The Beginning of the Renaissance in Castile and Leon, Cambridge, Mass., Harvard University Press, 1947, pp. 114-117; YOUNG, Eric, "A rediscovered painting by Pedro Berruguete and its companion panels", The Art Bulletin, 57/4 (diciembre 1975), pp. 473-475; CAMÓN AZNAR, José, Pintura del siglo XVI, Summa Artis, v. XXIV, Madrid, Espasa Calpe, 1970, p. 186; GARCÍA FELGUERA, María de los Santos (coord.), Pedro Berruguete, Madrid, Fundación Universitaria Española, 1985, p. 74; SILVA MAROTO, Pilar, Pedro Berruguete, Valladolid, Junta de Castilla y León, Consejería de Educación y Cultura, 1998, pp. 197-198 y 253-254; SILVA MAROTO, Pilar, "Restos de un retablo de la vida de la Virgen", en Pedro Berruguete. El primer pintor renacentista de la Corona de Castilla, Valladolid, Junta de Castilla y León, 2003, pp. 126-129. 


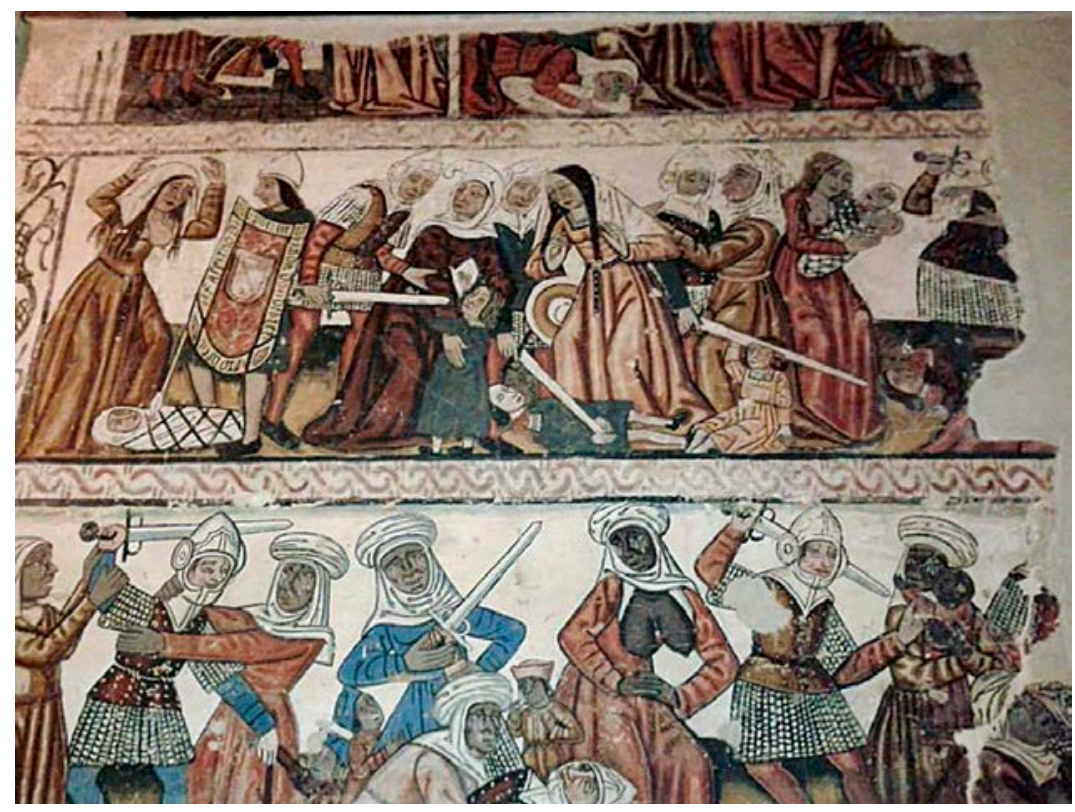

Fig. 5. La matanza de los inocentes. Comienzos del siglo XVI.

Catedral de Mondoñedo (Lugo)

certificar como testigos fidedignos el nacimiento de María, a quien la citada Leyenda dorada hace descendiente de la casa de David.

Otras nobles judías figuran representadas en los frescos de la catedral de Mondoñedo, de principios del siglo XVI y estilo hispanoflamenco ${ }^{34}$, originalmente situados en los muros del exterior del coro, que ocupaba los dos primeros tramos de la nave central. Se representa la Matanza de los Santos Inocentes, según San Mateo (2,16-18), en dos escenas que en total ocupan 15,75 metros en las que aparecen dos grupos de mujeres junto con los soldados encargados de ejecutar la masacre, uno de los cuales porta un escudo con la leyenda "Facemos por mandado del rey Erodes". En dichas pinturas aparece una mujer con tocado corniforme blanco y vestida con saya que, aunque no se puede ver, estaría ceñida con cinturón. Villaamil interpretaba

34 Descubiertos en el año 1862 por José Villaamil y Castro, quien los fechaba a fines del siglo XV. VILLAAMIL Y CASTRO, José, La catedral de Mondoñedo, su historia y descripción, sus pinturas murales, accesorios, mobiliario, bronces y orfebrería, vestiduras y ropas sagradas, Madrid, Manuel Galiano, 1865. Reed. corregida y aumentada con introducción de YZQUIERDO PERRÍN, Ramón, Estudios Mindonienses, 25 (2009), pp. 159-160. VILLAAMIL Y CASTRO, José, "Pinturas murales de la catedral de Mondoñedo", Museo Español de Antigüedades, 1 (1872), pp. 232-233; POST, Chandler Rathfon, A History of Spanish painting, v. IV, part I The HispanoFlemish style in North-Western Spain, Harvard University Press, 1933, Kraus reprint CO, New York, 1970, p. 478. 


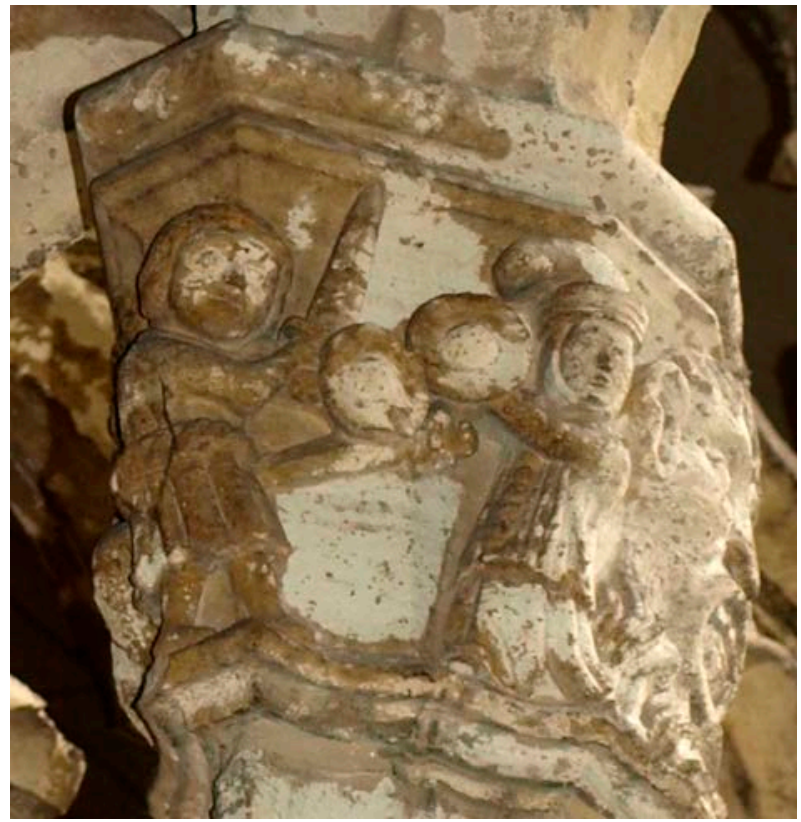

Fig. 6. Capitel del claustro de la catedral de Oviedo. 14121441. Foto: (C) Cabildo catedral de Oviedo, derechos reservados

la indumentaria y personas representadas como pertenecientes a dos razas o dos clases sociales diferenciadas, una de tez morena y con tocados blancos que no dejan ver más que el rostro, y otra de mejor condición que luce cabellos rubios y sueltos y con "maneras propias de persona distinguida, curioso tocado puntiagudo, caído hacia el lado derecho, de perfil muy semejante al de la antigua mitra de las amazonas, e igual al de los gorros frigios, que poco tiempo hace alcanzaron entre nosotros tanta boga" ${ }^{35}$. Nótese la asociación del autor con respecto a la mujer del tocado con alguien de alta alcurnia, pero puede ser que las pinturas sólo tratan de describir dos razas o dos culturas, sin establecer jerarquías, a menos que en la colocación de los grupos en altura se haya querido mostrar la jerarquía social, en cuyo caso la mujer del tocado corniforme estaría en la clase alta (Fig. 5). También es curiosa la asociación que Villaamil hace del tocado corniforme con el "gorro frigio", y la noticia de que estuviesen en uso hasta poco antes de su época.

Esta vinculación del tocado corniforme puede ser referida también a una nobleza simbólica y espiritual. En uno de los capiteles del claustro de la catedral de Oviedo, cuya ala oriental se construyó en tiempos del Obispo Diego Ramírez de Guzmán (1412-1441) ${ }^{36}$, se halla una mujer vestida lujosamente con un brial y cubierta con un tocado corniforme, la cual lucha lucha

35 VILLAAMIL Y CASTRO, José, “Pinturas murales...", p. 223.

36 CASO, Francisco de, La catedral de Oviedo..., v. 1, Oviedo, Nobel, 1999, pp. 88-92. 
con un hombre, ambos con espadas y escudos, resultando ella vencedora ${ }^{37}$. Podría tratarse de una Psychomachia o lucha de la Virtud contra el Vicio, siguiendo el texto de Prudencio escrito a mediados del siglo IV, el cual fue muy reproducido en imágenes de miniaturas altomedievales y después en la escultura románica. En estas representaciones en general las Virtudes visten túnicas largas y los Vicios cortas, combatiendo las primeras con espada o lanza y escudo, resultando siempre victoriosas, como sucede en el capitel de Oviedo. (Fig. 6).

El tocado corniforme en una figura de alto contenido simbólico noble figura también en una "misericordia" de la sillería del coro de la catedral de León, obra de Juan de Malinas hacia 1464-147538, donde aparece una mujer amamantando a un unicornio ${ }^{39}$, y con un tocado corniforme bastante alto y de similar apariencia a los de Silos. El tema fue explicado por San Isidoro en las Etimologías, identificando al unicornio con el rinoceronte (monoceron / unicornius):

"Según aseguran quienes han descrito la naturaleza de los animales, se le coloca delante de una joven doncella que le descubra su seno cuando lo ve aproximarse, y el rinoceronte, perdiendo toda su ferocidad, reposa en él su cabeza, y de esta forma adormecido, como un animal indefenso, es apresado por los cazadores" ${ }^{40}$.

En el Phisiologus ${ }^{41}$ hay una explicación similar y se menciona que este tema representa la castidad y a la Encarnación de Cristo en el seno de María

37 FERNÁNDE GUTIERRI, Gausón, El traje asturiano o traje del país, Oviedo, Caja Astur, 2007, p. 33.

38 El carpintero "maestro de las sillas" Enrique trabajaba en ellas desde 1462; y tras la muerte de Juan de Malinas en 1475, continuó la obra Copín de Holanda, entallador y carpintero, hasta 1481. TEIJEIRA PABLOS, María Dolores, "La última escultura gótica. Las obras del siglo XV", en YARZA, Joaquín, HERRÁEZ, María Victoria y BOTO, Gerardo, eds., La Catedral de León en la Edad Media. Actas del Congreso Internacional, León, Universidad de León, 2004, pp. 390-391; TEIJEIRA PABLOS, María Dolores y BOURNIORT, Jeanne, "Les stalles du groupe de León. Typologie et programme iconographique dans la sculpture gothique tardive espagnole", Revue de l'art, 114: 1 (1996), p. 57.

39 MATEO GÓMEZ, Isabel, Temas profanos en la escultura gótica española. Las sillerías de coro, Madrid, Instituto Diego Velázquez - CSIC, 1979, pp. 110-112, lám. XXIV, fig. 106. El tema de la dama y el unicornio aparece también en las sillerías de coro de las catedrales de Toledo y Sevilla.

40 SAN ISIDORO, Etimologías, XII, 2, 12-13.

41 Texto escrito en una cronología que varía según los diversos intérpretes entre los siglos II y IV en Egipto o Siria. DOCAMPO ÁLVAREZ, Pilar, MARTÍNEZ OSENDE, Javier y VILLAR VIDAL, José Antonio, "La versión C del Fisiólogo. 'El Codex Bongarsianus 318' de Berna”, Medievalismo, 10 (2000), pp. 55-56; DOCAMPO ÁLVAREZ, Pilar y VILLAR VIDAL, José Antonio, "El Fisiólogo latino: versión B: 2. Traducción y comentarios", Revista de Literatura Medieval, 15 (2003), p. 118. 
sacrificándose por la humanidad, basándose en los Salmos de David que hablan del unicornio y del "cuerno de salvación"42. La literatura posterior emblemática, en la que no aparecen los cazadores, extrajo del tema consecuencias morales: Joachim Camerarius en Symbolorum et Emblematum ex animalibus quadrupedibus (Nuremberg, 1595), lo coloca bajo el lema "Hoc virtutis amor", diciendo que la virtud puede tanto que vence a la misma fiera y en el grabado correspondiente aparecen los animales ponzoñosos huyendo de la doncella y el unicornio; en la Emblemata de Nicolas Reusner (1581) el lema es "Victris casta fides"; y en La Celestina (acto IV), el unicornio, considerado animal piadoso, se humilla ante cualquier doncella. La mujer representa a la Virtud o incluso a la Virgen María nutriendo a Jesucristo. En las ilustraciones del Phisiologus y de los Bestiarios la mujer puede aparecer desnuda o amplia y lujosamente vestida, opción esta última elegida en la "misericordia" leonesa, que mantiene la coherencia al representar el tocado corniforme en una mujer amamantando, por tanto no una doncella virgen, pero sí en relación con la Virgen María como dice el Phisiologus.

En los ejemplos de Langa del Castillo y de Santo Domingo de la Calzada, las portadoras del tocado corniforme están bajo la protección de la Virgen y de Santo Domingo, y probablemente figuran también como nobles.

En el retablo mayor de la iglesia de San Pedro de Langa del Castillo, encontramos en el primer cuerpo del lado de la Epístola una tabla dedicada a la Virgen de la Misericordia ${ }^{43}$, de 1425, con la figura de una mujer con tocado corniforme entre las protegidas por el manto de la Virgen ${ }^{44}$. En la imagen, la Virgen acoge bajo su manto, a su derecha a los fieles varones, y a su izquierda a las mujeres, entre las cuales aparece en segundo plano una de edad madura que porta el tocado corniforme, de color blanco, con forma de tubular y sobre la frente una banda con un bordado dorado (Fig. 7). Su forma y dispo-

42 Salmos 21, 22: "Salva me ex ore leonis, et a cornibus / unicornium humilitatem meam"; 28, 6: "et dilectus quemadmodum filius unicornium"; 77, 69: "Et aedificavit sicut unicornium sanctificium / suum, in terra quam fundavit in saecula"; y 91, 11: "Et exaltabitur sicut unicornis cornu meum / et senectus mea in misericordia uberi". También en Isaías, 34, 7.

43 El tipo iconográfico de la Virgen de la Misericordia que incorpora en primer plano al Papa con la capa roja o "capa magna" puede verse ya en una clave de la catedral de Barcelona, de 1379; y también en una tabla del Palacio Episcopal de Teruel, obra de artista aragonés desconocido. Sobre esta iconografía, KUGLER, Katrena Swope, Bridging Heaven and Spain; The Virgin of Mercy from the Late Medieval period to the Age of exploration, Tesis Doctoral, University of Oregon, 2013.

44 Este retablo había sido atribuido a un artista al que se había llamado "Maestro de Langa" pero en últimos estudios se atribuye con alguna reserva a Martín del Cano, pintor de Daroca. MAÑAS BALLESTÍN, Fabián, "Pintura gótica en el Campo Romanos. IV. El retablo mayor de la iglesia de Langa del Castillo", Revista Zaragoza, 26 (sept. 1981), pp. 24-26; MAÑAS BALLESTÍN, Fabián, "Las artes en época medieval", en Comarca del Campo de Daroca, Zaragoza, Departamento de Presidencia y Relaciones, 2003, pp. 159-160. 


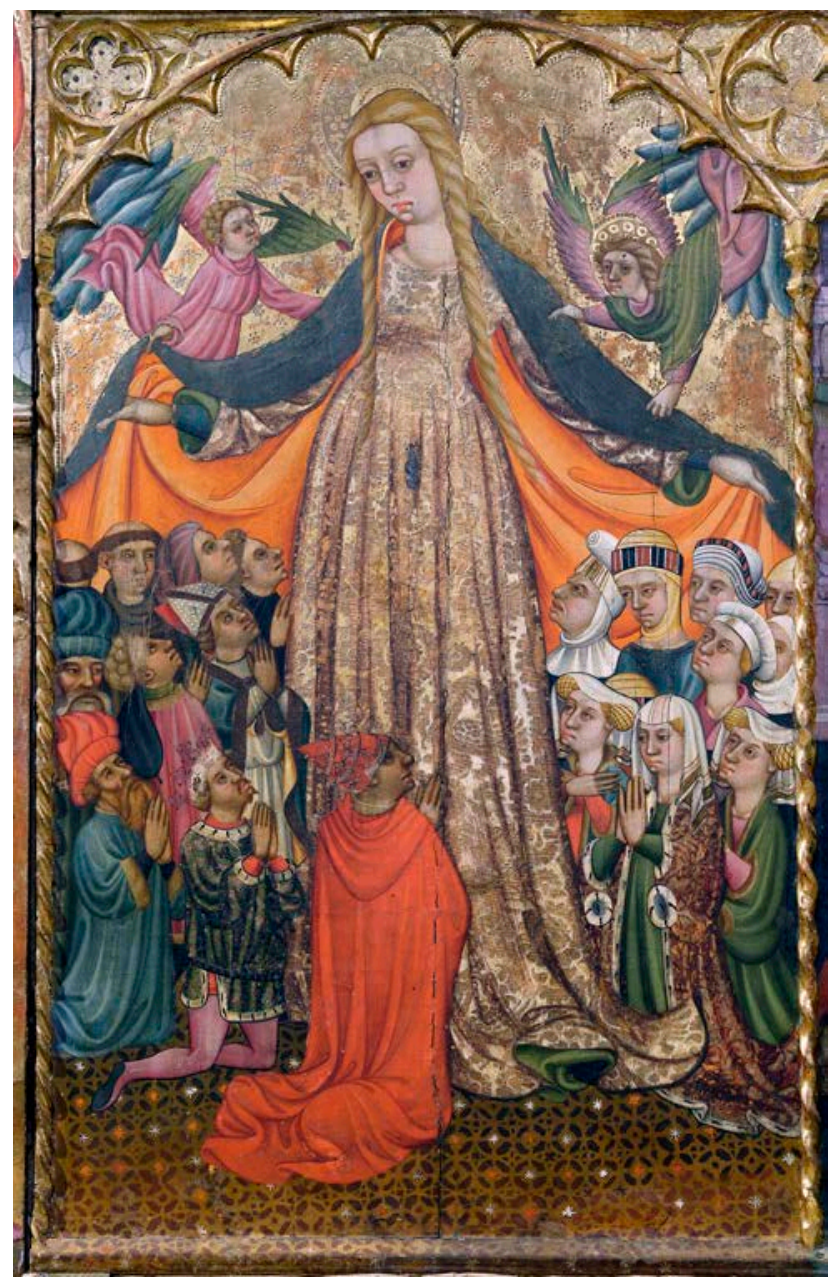

Fig. 7. Virgen de la Misericordia. H. 1425 . Retablo mayor de la iglesia de San Pedro, Langa del Castillo (Zaragoza). Foto: Aurelio Á. Barrón

sición recuerdan a los de "Doña Teresa" de la iglesia de Sinovas, en Burgos, y es muy similar a la de un tocado en un friso de la capilla del Condestable de la catedral de Burgos (Simón y Francisco de Colonia, 1482-1517), que Juan José Calzada Toledano considera un "aristócrata" 45 . Los personajes que figuran bajo la protección de la Virgen en Langa del Castillo son en general de clase social elevada, como se puede ver mejor en el grupo de los varones, donde figuran el Papa con la capa roja y mitra con triple corona, un obispo y un rey, pero también un monje. Entre las mujeres se puede ver una con joyas sobre el pecho situada junto a la que porta el tocado corniforme, y en general todas llevan tocados sofisticados, identificando una clase social elevada.

En la catedral de Santo Domingo de la Calzada, en el sepulcro del Santo,

45 CALZADA TOLEDANO, Juan José, Escultura Gótica Monumental en la provincia de Burgos. Iconografía 1400-1530, Burgos, Diputación Provincial, 2006, p. 82, fig. 51. 


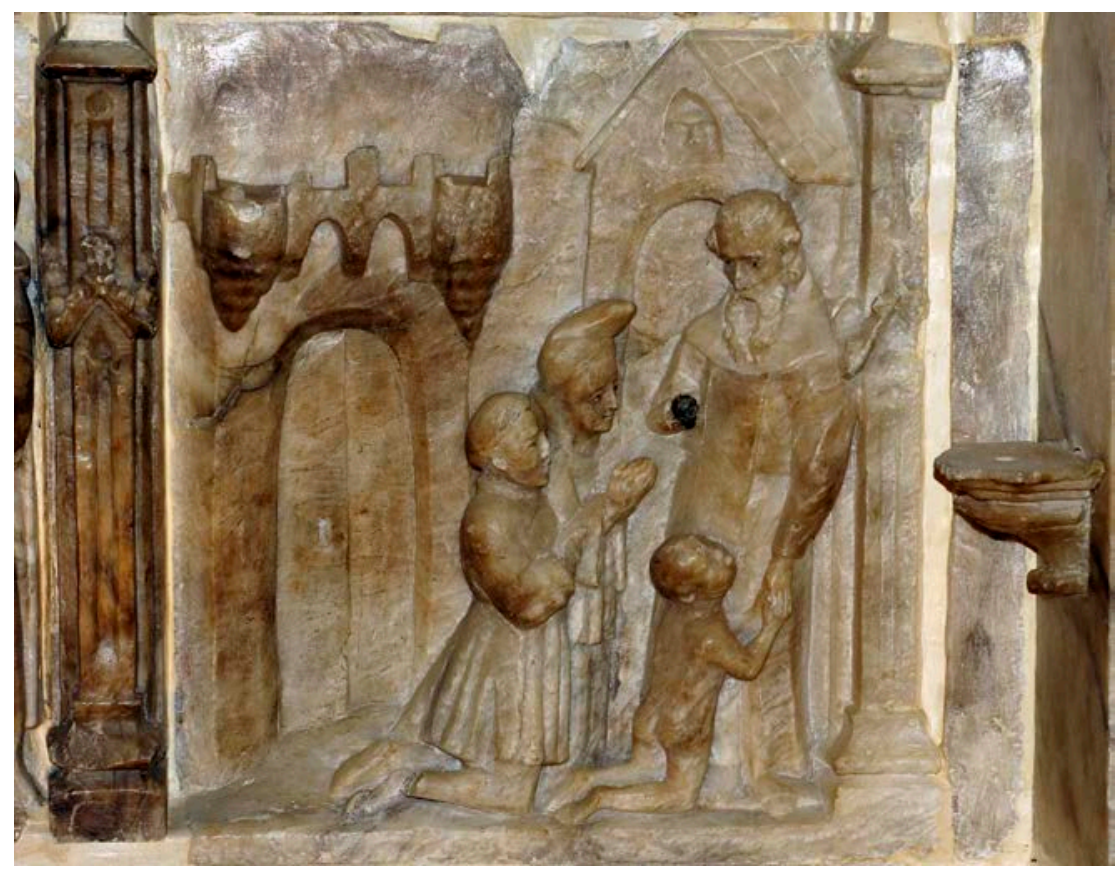

Fig. 8. Sepulcro de Santo Domingo de la Calzada, detalle. H. 1440. Catedral de Santo Domingo de la Calzada (La Rioja). Foto: Aurelio Á. Barrón

esculpido en alabastro hacia 1440, figura una escena de un milagro de Santo Domingo donde aparece una mujer con el tocado corniforme (Fig. 8). Entre los diversos milagros de Santo Domingo, fray Luis de la Vega menciona en 1606 el suceso en el que el Santo resucita al hijo de una pareja de peregrinos ${ }^{46}$. Luis de la Vega menciona en su libro que la serie de milagros debidos a Santo Domingo mientras construía el puente de dicha localidad, entre ellos éste, no habían quedado reflejados por escrito, pero existía un retablo dedicado a San Sebastián en la iglesia de Santo Domingo que él fechaba más de trescientos años antes (1303), "y en él están entallados estos milagros". Este retablo sería la fuente iconográfica utilizada para componer las diversas biografías del Santo y posiblemente también para las escenas insertas en su Sepulcro. El milagro lo citan también José González de Tejada en 1702, que añade por su cuenta que los peregrinos eran "extranjeros" ${ }^{47}$, y el padre fray Mateo de Anguiano en $1704^{48}$. La portadora del tocado figura orante junto a su esposo,

46 VEGA, fray Luis de la, Historia de la vida y milagros de Santo Domingo de la Calzada, Burgos, Juan Bautista Varesio, 1606, p. 53.

47 GONZÁlEZ DE TEXADA, Joseph, Historia de Santo Domingo de la Calzada, Abrahan de la Rioja, Madrid, Viuda de Melchor Álvarez, 1702, p. 80.

48 ANGUIANO, fray Matheo de, Compendio historial de la Provincia de La Rioja, de sus Santos, y milagrosos Santuarios, Madrid, Antonio Gonçalez de Reyes, 1704, p. 104. 


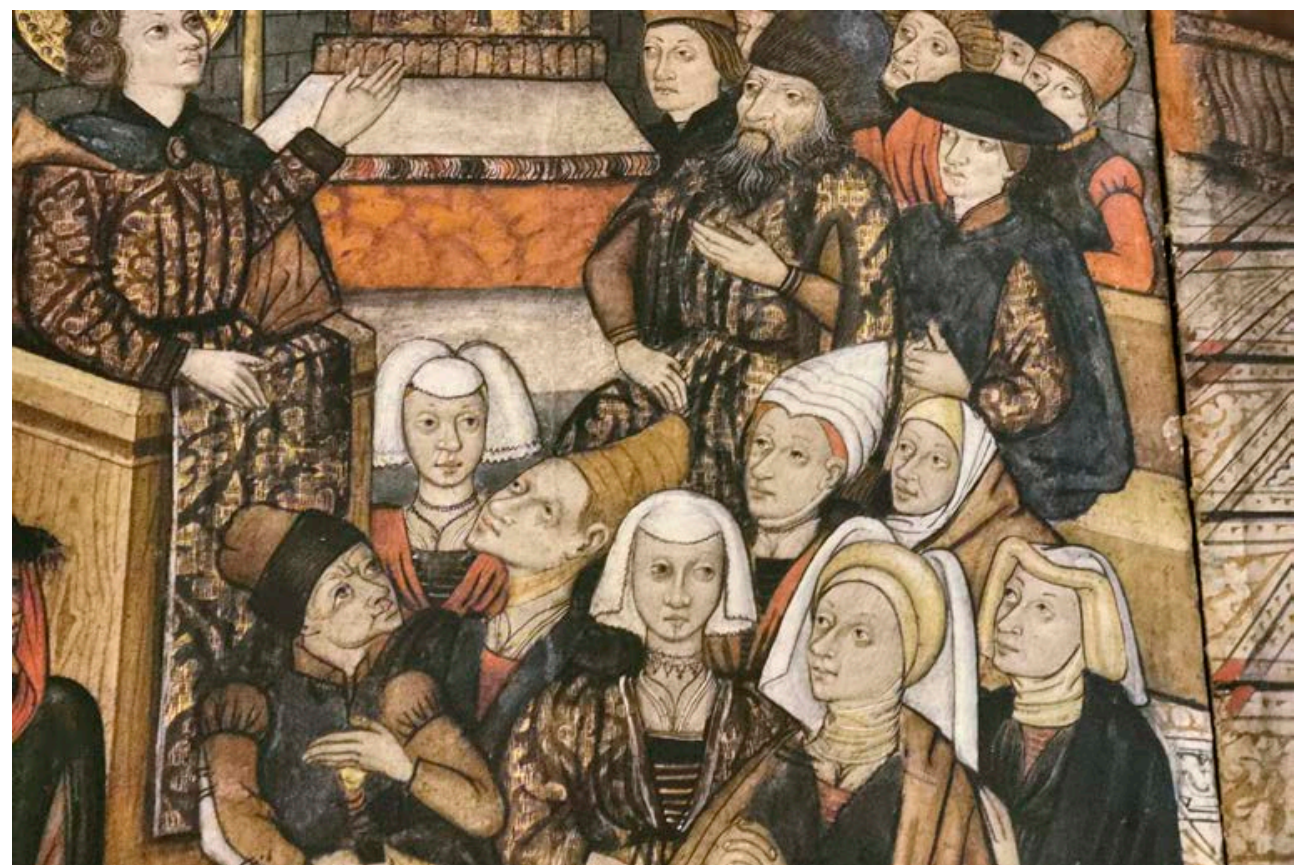

Fig. 9. Retablo de San Juan Evangelista, detalle. 1435-1450. Iglesia de Nuestra Señora de la Peña, Ágreda (Soria). Foto: Archivo Parroquial de Agreda

y lleva un tocado corniforme abierto por abajo, de similar apariencia, con la punta más bien roma, a los mencionados antes de Sinovas y Langa del Castillo, aunque este ultimo presenta una estructura en forma de rollo que no se aprecia en el de Santo Domingo. La vestimenta del marido indica una clase social elevada, haciendo suponer que se trata de peregrinos nobles.

En la iglesia de Nuestra Señora de la Peña en Âgreda (Soria) aparece una mujer con tocado corniforme en una de las tablas del retablo de San Juan Evangelista, en la cual San Juan predica ante un grupo de seguidores en Éfeso, obra datada entre los años $1435-1450^{49}$, o más precisamente $1430-1445^{50}$.

49 HERNÁNDEZ MARTÍNEZ, José, Historia de Ágreda, Tarazona, Félix Meléndez, 1911, pp. 107-108; ALCOLEA, Santiago, Soria y su provincia, Barcelona, Aries, 1964, p. 87; TARACENA, Blas y TUDELA, José, Guía Artística de Soria y su provincia, Madrid, Eosgraf, 1973 (1를. ed., Soria, imprenta Hera, 1928), p. 234; PEÑA GARCÍA, Manuel, Ágreda: Santa María de los Milagros. Libro del peregrino, Soria, Unión Gráfica, 1979, p. 41; ORTEGO Y FRÍAS, Teógenes, Ágreda, bastión de Castilla hacia Aragón, Soria, Caja de Ahorros y Préstamos de la Provincia de Soria, 1980, p. 89; CARDONA JIMÉNEZ, Verónica, La pintura gótica en la Villa de Ágreda (siglo XV, Junta de Castilla y León, Consejería de Cultura y Turismo, 2006, p. 110.

50 LACARRA DUCAY, María del Carmen, "Retablo de San Juan Evangelista”, en La Ciudad de Seis Pisos. Las Edades del Hombre. El Burgo de Osma. Soria. 1997. Madrid, Fundación "Las Edades del Hombre", 1997, p. 223. 
Verónica Cardona apunta que las vestimentas, joyas y tocados que aparecen podrían estar importados de la corte de Borgoña, con lo que suponemos que sugiere su posible relación con el Henin, teoría de la que ya habíamos hablado anteriormente. En cambio, María del Carmen Lacarra Ducay menciona que "el público, hombres y mujeres de diferente edad y condición, viste a la moda española del segundo cuarto del siglo $\mathrm{XV}^{\prime \prime 51}$. El tocado en este caso es de un color amarillento, en contraste con los demás tocados existentes en la escena; y es más abierto de lo visto hasta ahora, dejando ver orejas y pelo. A su lado hay otra mujer con un tocado blanco, aunque de estructura algo diferente (Fig. 9).

\section{4. ¿UN TOCADO POPULAR?}

Existe un ejemplo del siglo XV en el que se muestra el tocado corniforme en un contexto popular. En la catedral de León, en el actual retablo mayor, encontramos en una de las tablas de Nicolás Francés, que trabajó en León entre 1434 y 1468, la representación del Traslado de las reliquias de Santiago, con la historia de la reina Lupa ${ }^{52}$. El cuerpo del apóstol es transportado en un carro tirado por bueyes, y en segundo plano figura una pastora que porta un tocado corniforme, de color blanco, enrollado formando un cono e inclinado hacia delante, con el rebozo tapando la barbilla. Este es el único caso de la época que conocemos en que el tocado corniforme es portado por una campesina, contrastando con lo que sucede en los casos hasta ahora vistos, en los que era lucido por mujeres nobles. Nicolás Francés, cuyo estilo se forma en el ámbito parisino, pinta con frecuencia personajes secundarios: "Como siempre, no prescinde de lo secundario, por eso vemos a un pastor y a una pastora que contemplan con cara de asombro el cortejo de los bueyes dirigidos por los discípulos" ${ }^{\prime 53}$. Los pastores recuerdan a las representaciones del Anuncio a los pastores en el siglo $\mathrm{XV}$, donde a veces se incluye una mujer y uno de ellos protege la vista de la luz desprendida por el ángel anunciador. Las ovejas tienen un significado simbólico dentro de esta historia, representan-

51 LACARRA DUCAY, María del Carmen, “Retablo de San Juan...”, p. 223.

52 La reina engaña a los dos discípulos de Santiago y les envía al monte Sacro para que cojan dos bueyes mansos, en realidad toros bravos, pero ellos consiguieron su mansedumbre. En la tabla, los discípulos pasan con el cuerpo de Santiago delante del palacio de la reina, que se convierte. REBOLLO GUTIÉRREZ, Carmen, “Maese Nicolás Francés: su obra y estilo, estado de la cuestión" en De Arte: Revista de Historia del Arte, 6 (2007), p. 124. La datación tradicional de la obra la fechaba antes de 1434, pero se ha apuntado que podría ser posterior a dicha fecha: YARZA LUACES, Joaquín, "Artes del color en el siglo XV en la catedral de León”, en YARZA, Joaquín, HERRÁEZ, María Victoria y BOTO, Gerardo, eds., La Catedral de León en la Edad Media. Actas..., pp. 401-402.

53 YARZA LUACES, Joaquín, “Artes del color...", p. 411. 


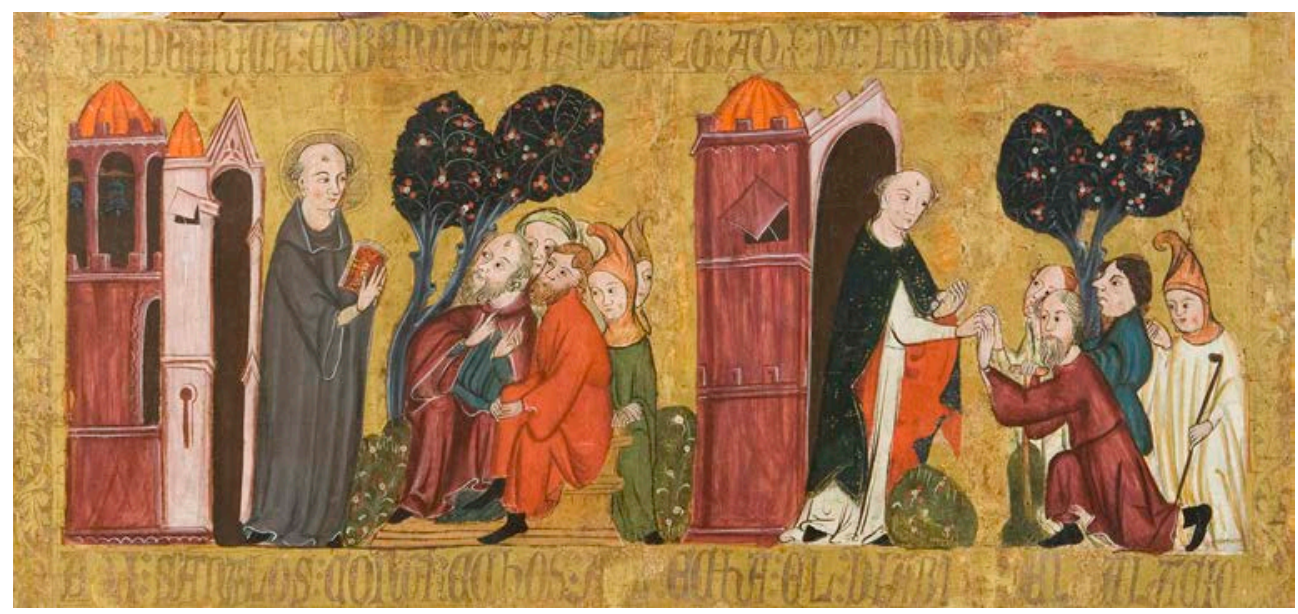

Fig. 10. San Millán predicando y dando limosna. 1390-1410. Tríptico con escenas de la vida de San Millán, procedente de San Millán de la Cogolla (La Rioja). Museo de La Rioja, no de inventario 400

do la mansedumbre en relación con los toros que milagrosamente se transforman en pacíficos bueyes ("mansos como corderos"), y por eso la escena de los pastores con las ovejas, con sus corderos, está en un lugar destacado en el centro de la escena, inmediatamente por encima de los bueyes. Así lo relata la Leyenda áurea, mencionando "corderos": "E hizieron la señal de la cruz sobre los toros y luego fueron tan mansos como corderos; y uneroslos y pusieron la piedra sobre el carro con el cuerpo de Santiago, y los toros sin guiamiento alguno traxeron el cuerpo de Santiago en medio del palacio de la reyna Loba" ${ }^{54}$. Y no se escapa tampoco la contraposición entre las ovejas y la Loba. Esta pintura, junto con el testimonio de Arnold von Harff de que el tocado corniforme se usaba ordinariamente en el Bearne a fines del siglo $\mathrm{XV}$, son las únicas pruebas de que este tipo de tocado se empleaba fuera de las clases elevadas.

La investigación sobre el tocado corniforme debe hacerse con rigor, estudiando el contexto en que esta prenda aparece. De este modo se pueden evitar confusiones con otros tipos de tocados similares. Ejemplo de ello son los tocados que aparecen en una tabla del Museo de La Rioja, en Logroño (Fig. 10), perteneciente a un tríptico procedente del Monasterio de Suso en San Millán de la Cogolla. En una de las escenas de la vida de San Millán se muestra al santo predicando ante un grupo en el que aparecen algunas figuras con tocados aparentemente corniformes y otra escena donde reparte limosnas a algunas personas entre las que se halla otra figura con este mismo

54 Leyenda de los Santos que vulgarmente Flos Santorum llaman, Toledo, Iuan Ferrer, 1554, f. CVIII. 
tocado. De autor anónimo, pintadas al temple, esta obra se puede fechar entre 1390 y 1410, teniendo en cuenta la indumentaria de los personajes, con la presencia de mangas anchas hasta el antebrazo ceñidas por botones ("mangas a fondón de cuba") utilizadas hacia 1385, y otras características de ese tiempo. Aunque en un primer momento pudiésemos suponer que son mujeres, se trata de figuras masculinas, como Sánchez Trujillano ya ha señala$\mathrm{do}^{55}$. Al repasar los versos de Gonzalo de Berceo sobre la vida de San Millán encontramos reflejadas en las estrofas 96 y 97 las dos escenas de las tablas, en cuyos versos se especifica que San Millán predicaba "con legos e con clérigos". Lo que estos clérigos llevan en la cabeza podría tratarse de capirotes, prenda masculina que usaron también las mujeres a partir del siglo XIV durante un corto espacio de tiempo y que dejaron de usar en el siglo siguiente.

\section{Conclusiones}

Los tocados corniformes son representados en la Baja Edad Media como imágenes con significados religiosos o literarios caballerescos, y no pueden ser analizadas por tanto como mero reflejo de la realidad, por lo que para entenderlas han de ser analizadas como tales imágenes, mostrando su contexto formal, estilístico, iconográfico o social.

A la vista de los ejemplos de tocados corniformes aquí citados, podemos situar su origen en la Meseta norte peninsular en la segunda mitad del siglo XIV, extendiéndose su uso en la Baja Edad Media en una amplia área entre Galicia y Aragón, teniendo sus ejemplos más extremos en Mondoñedo y en el Bearne, pero su centro parece estar en el área burgalesa. Coincide este desarrollo con el cambio general producido en el vestido desde mediados de dicho siglo, con la aparición de la moda, la clara diferenciación del vestido masculino y femenino, y su uso muy evidente por la nobleza para representar su estatus.

Las imágenes encontradas proceden en primer lugar de talleres de pintura sobre alfarjes en el área burgalesa, y después hay obras tanto en pintura como en escultura de artífices procedentes de Flandes y Francia (Juan de Malinas, Nicolás Francés, Felipe Bigarny), o de talleres dirigidos por ellos, o bien de españoles (Pedro Berruguete y otros anónimos como el "Maestro de Mondoñedo" o el "Maestro de Langa", quizá Martín del Cano). Una fuente de información la constituyen los relatos de viajeros a Santiago de Com-

55 SÁNCHEZ TRUJILLANO, María Teresa, “Estudio ambiental de las Tablas de San Millán, indumentaria", en Segundo coloquio sobre Historia de La Rioja, Logroño, Colegio Universitario de La Rioja, 1986, v. III, p. 83. Agradecemos a Consuelo Sanz de Bremond que nos haya llamado la atención sobre este tema. De esta autora véase el blog “El capirote, chaperón, capirón (1)", http://opusincertumhispanicus.blogspot.com/ 
postela, procedentes de Alemania, Flandes o Francia y de los cronistas que acompañaron a los viajeros regios, en su camino entre Inglaterra y Flandes y los puertos del norte peninsular.

Estos tocados fueron estudiados por vez primera por autores franceses (Ducéré) y españoles (Villaamil) en la segunda mitad del siglo XIX; y después a principios del siglo XX por eruditos, escritores e investigadores vascos en lo relativo al territorio vasco-navarro (Manso de Zúñiga, Gárate Arriola, Caro Baroja, etc. $)^{56}$, y a partir de 1970 por autores asturianos, cántabros y castellanos (Nieves de Hoyos, Gustavo Cotera, José Luis Casado, etc.). Pero su atención se dirigió sobre todo a los siglos XVI y XVII en la cornisa cantábrica.

Mucho se ha especulado en torno a su origen, existiendo un debate al respecto. La teoría de su procedencia del Henin vendría reforzada por la rápida expansión del arte y los artistas flamencos a lo largo de las principales vías de comunicación de la época y podría explicarse como una reinterpretación local del tocado borgoñón, aunque como señalase en su momento Gonzalo Manso de Zúñiga, difería de éste en cuanto a su estructura y forma, siendo el uno rígido y el otro más curvo. Existieron anteriormente en la Península tocados altos en la Hispania antigua como ya reseñó Julio Caro Baroja, pero lo suficientemente alejados en el tiempo para que no tuviesen influencia en el Medievo hispánico, en el cual hubo también tocados altos como se aprecia en el Códice Emilianense que se conserva en la biblioteca del Monasterio de San Lorenzo del Escorial. Las fuentes de la época hablan de una influencia pagana, como se deduce del relato recogido por el cronista flamenco Laurent Vital en Ribadesella en 1517, y de un significado fálico, como se señaló en el siglo XVI, y como modernamente se ha incorporado al debate. Se observa la casi total ausencia de testimonios y opiniones de los naturales, frente a los viajeros externos, y especialmente de las mujeres que los usaron, lo que nos lleva a la conclusión de que no sabemos realmente el significado que éstos les atribuyeron más allá de la distinción entre casadas y solteras y un símbolo de estatus social que parece relacionar el tocado corniforme con una clase social elevada, de tal modo que cuanto más alto era el tocado, denotaba mayor riqueza económica. No obstante, algunos testimonios del siglo XV permiten decir que en esta época el tocado corniforme podría ya haberse popularizado.

Ya en el siglo XVI aparecen las primeras colecciones de dibujos de trajes coincidiendo con la subida al trono de Carlos I. Estos álbumes consistían en recopilaciones sobre la ropa y costumbres a través de imágenes de Europa, Asia, África y América, y cambiarán el modo en que aparecen los vestidos,

56 Además de la bibliografía ya citada, GARMENDIA GOYETCHE, Pedro, "Trajes vascos del siglo XVI", Revista internacional de los estudios vascos, 25/3 (1934), pp. 521-522; 26/1 (1935), pp. 153-154; 27/1 (1936), pp. 128-129. 
ya no en un contexto religioso o literario sino como muestrario de la diversidad de las diferentes culturas. El emperador Carlos auspició la creación de estos álbumes de trajes vinculados a la corte de los Habsburgo, a través de Christof Weiditz (h. 1500-1559), autor de su Trachtenbuch en 1529, y de Christoph Von Sternsee (h. 1549), capitán de la Guardia Alemana de Carlos V y autor de su Costume Album (h. 1549). Incluso hubo un coleccionista francés, François Roger de Gaignieres (1642-1715) que recopiló diversos álbumes de dibujos de trajes, contribuyendo a su difusión, incrementada cuando estos dibujos fueron llevados en muchos casos al grabado, adquiriendo una difusión hasta entonces desconocida ${ }^{57}$.

\section{Bibliografía}

ALCOLEA, Santiago, Soria y su provincia, Barcelona, Aries, 1964.

ANGUIANO, fray Matheo de, Compendio historial de la Provincia de La Rioja, de sus Santos, y milagrosos Santuarios, Madrid, Antonio Gonçalez de Reyes, 1704; (ed. MOYA VALGAÑÓN, José Gabriel (intr.), Logroño, Consejería de Educación, Cultura y Deportes, 1985).

BARANDA, Nieves, "Los problemas de la historia medieval de Flores y Blancaflor", DICENDA, Cuadernos de Filología Hispánica, 10 (1991-92), pp. 21-39; disponible: http://www.cervantesvirtual.com/obra/los-problemas-de-la-historia-medieval-de-flores-y-blancaflor/

BARRÓN GARCÍA, Aurelio Á., “La obra de Felipe Bigarny en Haro: a propósito de dos imágenes inéditas del retablo de Santo Tomás de Haro (La Rioja)", Artigrama, 31 (2016), pp. 347-359; disponible: https://www.unizar.es/artigrama/ pdf/31/3varia/03.pdf

BOND, Katherine Louise, Costume Albums in Charles V's Habsburg Empire (1528-1549), Tesis Doctoral, University of Cambridge, 2017; disponible: https://www.repository.cam.ac.uk/handle/1810/277715

BRAUN, Georg y HOGENBERG, Franz, Civitates Orbis Terrarum, Colonia, Apud Auctores, 1572-1618; disponible: https://bvpb.mcu.es/es/catalogo_imagenes/ grupo.do?path $=162633$

CALZADA TOLEDANO, Juan José, Escultura Gótica Monumental en la provincia de Burgos. Iconografía 1400-1530, Burgos, Diputación Provincial, 2006.

CAMÓN AZNAR, José, Pintura del siglo XVI, Summa Artis, v. XXIV, Madrid, Espasa Calpe, 1970.

CAPDEVILA, Miguel, Iconografía de Santa Lucía, Masnou (Barcelona), Laboratorios

57 VICO, Enea, Diversarum Gentium nostrae aetatis habitus, Venecia, 1557; reed., Ferdinandus Bertelli Arreis, 1569; DESPREZ, François, Recueil de la diversité des habits, qui sont de present en usage, tant es pays d'Europe, Asie, Afrique, E Isles sauvages. Le tout fait apres le naturel, París, Richard Breton, 1567; VECELLIO, Cesare, Degli habiti antichi et moderni di diversi parti del mondo, Venecia, Damiano Zenaro, 1590; reed. Habiti antichi et moderni di tutto il mondo, Venecia, Giovanni Bernardo Sessa, 1598; BRAUN, Georg y HOGENBERG, Franz, Civitates Orbis Terrarum, Colonia, Apud Auctores, 1572-1618. 
del Norte de España, 1949.

CARDONA JIMÉNEZ, Verónica, La pintura gótica en la Villa de Ágreda (siglo XV), Junta de Castilla y León, Consejería de Cultura y Turismo, 2006.

CARO BAROJA, Julio, Los pueblos de España. Ensayo de etnología, Barcelona, Barna, 1946.

CASO, Francisco de, La Catedral de Oviedo, v. 1, Oviedo, Nobel, 1999.

CONCEJO DÍEZ, María Luisa, El arte mudéjar en Burgos y su provincia, Tesis Doctoral, Universidad Complutense de Madrid, 1999; disponible: http://webs.ucm.es/ BUCM/tesis/19972000/H/0/H0039801.pdf

COTERA, Gustavo, El traje en Cantabria, Santander, Cantabria, 1999.

DESPREZ, François, Recueil de la diversité des habits, qui sont de present en usage, tant es pays d'Europe, Asie, Afrique, E Isles sauvages. Le tout fait apres le naturel, París, Richard Breton, 1567; disponible: https://gallica.bnf.fr/ark:/12148/bpt6k87071655/ f1.item y https://www.metmuseum.org/art/collection/search/348625

DOCAMPO ÁLVAREZ, Pilar, MARTÍNEZ OSENDE, Javier y VILLAR VIDAL, José Antonio, "La versión C del Fisiólogo. 'El Codex Bongarsianus 318' de Berna", Medievalismo, 10 (2000), pp. 27-68; disponible: https://revistas.um.es/medievalismo/article/view/51801

DOCAMPO ÁLVAREZ, Pilar y VILLAR VIDAL, José Antonio, “El Fisiólogo latino: versión B: 2. Traducción y comentarios", Revista de Literatura Medieval, 15 (2003), pp. 107-157; disponible: https://ebuah.uah.es/dspace/handle/10017/5436

DUCÉRÉ, Etienne-Edouard, "Les noms d'étoffes et de vêtements en Basque", Revue de la linguistique et de philologie comparée", 28 (15 abril 1883), pp. 1-43; disponible: http://gordailu.bilketa.eus/notice.php?q=id:543726

DUCÉRÉ, Etienne-Edouard, "La bourgeoisie bayonnaise sous l'Ancien Régime (moeurs, usages et costumes)", Bulletin de la Société des Sciences, Lettres et Arts de Pau, II Serie/18 (1889), pp. 89-247; disponible: https://gallica.bnf.fr/ark:/12148/ bpt6k342708?rk=21459;2

FABIÉ, Antonio María (ed.), Viajes por España, de Jorge de Einghen, del Barón de Rosmithal de Blatna, de Francisco Guicciardini y de Andrés Navajero, traducida, anotada y con una introducción por Don Antonio María Fabié, de la Academia de la Historia, Madrid, Librería de los Bibliófilos Fernando Fé, 1879; disponible: http://www. bibliotecavirtualdeandalucia.es/catalogo/es/consulta/registro.cmd?id=1000475

FERNÁNDE GUTIERRI, Gausón, El traje asturiano o traje del país, Oviedo, Caja Astur, 2007.

FURNIVALL, Frederick James (ed.), The fyrst boke of the introduction of knowledge made by Andrew Borde, of physycke doctor. A compendyous regyment, or, A dyetary of helth made in Mountpyllier, Londres, N. Trübner \& Co., 1870. Eds. modernas: Hansebooks, Nordestedt, 2017; y Maroussi, Alpha Editions, 2019; disponible: https:// wellcomecollection.org/works/hxbxustk

GACHARD, Louis Prosper y PIOT, Charles, Collection des voyages des souverains des Pays-Bas. Tomo III, Bruselas, F. Hayez, 1881; disponible: https://books.google. es/books/about/Collection_des_voyages_des_souverains_de.html?id=u4xDAAAAYAAJ\&redir_esc $=y$

GÁRATE ARRIOLA, Justo, "Ensayo sobre el tocado corniforme", Revista de Estudios 
Vascos, 1/ 2 (marzo-abril 1947), pp. 231-243; disponible: https://w390w.gipuzkoa. net/WAS/CORP/DBKVisorBibliotecaWEB/visor.do?ver\&amicus=41841

GARCÍA FELGUERA, María de los Santos (coord.), Pedro Berruguete, Madrid, Fundación Universitaria Española, 1985.

GARCÍA MERCADAL, José, Viajes de extranjeros por España y Portugal desde los tiempos más remotos hasta fines del siglo XVI, Salamanca, Junta de Castilla y León, 1999.

GARMENDIA GOYETCHE, Pedro, "Trajes vascos del siglo XVI", Revista internacional de los estudios vascos, 25/2 (1934), pp. 274-282; 25/3 (1934), pp. 521-524; 26/1 (1935), pp. 151-154; 27/1 (1936), pp. 128-133; disponible: http://www. eusko-ikaskuntza.eus/PDFAnlt/riev/25/25274282.pdf; http://www.eusko-ikaskuntza.eus/PDFAnlt/riev/25/25521524.pdf; http://www.eusko-ikaskuntza.eus/ PDFAnlt/riev/26/26151154.pdf; y http://www.eusko-ikaskuntza.eus/PDFAnlt/ riev/27/27126133.pdf

GAVEL, Henri, "Un pelerin de Saint-Jacques au Pays Basque a la fin du XVe siècle", en VV.AA., Cómo han sido y cómo son los vascos. Izakera ta jazkera. Carácter e indumentaria, San Sebastián, Auñamendi, 1975, v. II, pp. 239-272.

GAYANGOS DE RIAÑO, Emilia, Viaje de España por un anónimo: 1446-8, Traducido directamente del Alemán por E.G.R., Madrid [s.n.], Tipo-litografía de V. Faure, 1883; disponible: https://data.historicaltexts.jisc.ac.uk/view?pubId=bl-003455134

GIESE, Wilhelm, Contribución al estudio del problema del antiguo tocado corniforme de las mujeres vascas: Homenaje a D. Julio de Urquijo, Hamburgo, Paul Evert, 1937.

GÓMEZ GÓMEZ, Agustín, "La techumbre mudéjar de Sinovas", Biblioteca. Estudio e Investigación, 17 (2002), pp. 71-90; disponible: https://dialnet.unirioja.es/ejemplar/162609

GONZÁLEZ DE TEXADA, Joseph, Historia de Santo Domingo de la Calzada, Abrahan de la Rioja, Madrid, Viuda de Melchor Álvarez, 1702; disponible: https://bvpb. mcu.es/es/consulta/registro.do?id=411669

GONZÁLEZ MUELA, Joaquín (ed.), Libro del caballero Zifar, Madrid, Editorial Castalia, 1982.

GROOTE, Eberhard von, Die Pilgerfahrt der Ritters Arnold von Harff von Cöln durch Italien, Syrien, Aegypten, Arabien, Aethiopien, Nubien, Palästina, die Türkei, Frankreich und Spanien, wie er sie in den Jahren 1496-1499, Colonia, J. M. Heberle, 1860; disponible: http://wpd.ugr.es/ hum138/textos/europeos/arnold_1860.pdf y https://www.digitale-sammlungen.de/de/view/bsb10466975?page $=285$

HARFF, Arnold von, Die pilgerfahrt des ritters Arnold von Harff von Cöln, Oxford, Bodleian Library, MS, Bodleian 972, f. 144v; disponible: https://digital.bodleian.ox.ac.uk/objects/9eb27b9a-6d1b-40b3-97db-fda64e5a2ab9/

HERNÁNDEZ MARTÍNEZ, José, Historia de Ágreda, Tarazona, Félix Meléndez, 1911. JUAN LOVERA, Carmen, "El alfarje del Buen Amor", en TORO CEBALLOS, Francisco y GODINAS, Laurette (coord.), Juan Ruiz, Arcipreste de Hita, y el Libro de buen amor. III Congreso Internacional Congreso homenaje a Jacques Joset; disponible: https://cvc.cervantes.es/literatura/arcipreste_hita/03/juan.htm

KUGLER, Katrena Swope, Bridging Heaven and Spain; The Virgin of Mercy from the Late Medieval period to the Age of exploration, Tesis Doctoral, University of Ore- 
gon, 2013; disponible: https://scholarsbank.uoregon.edu/xmlui/bitstream/handle/1794/13246/Kugler_oregon_0171N_10671.pdf

LACARRA DUCAY, María del Carmen, "Retablo de San Juan Evangelista", en La Ciudad de Seis Pisos. Las Edades del Hombre. El Burgo de Osma. Soria. 1997, Madrid, Fundación "Las Edades del Hombre", 1997.

LAÍNEZ ALCALÁ, Rafael, Pedro Berruguete, pintor de Castilla, Madrid, Espasa Calpe, 1935.

MANSO DE ZÚÑIGA, Gonzalo, "Tocados medievales", Boletín de la Real Sociedad Bascongada de los Amigos del País, 7/4 (1951), pp. 505-510; disponible: https:// www.rsbap.org/ojs/index.php/boletin/article/view/2543/2410

Leyenda de los Santos que vulgarmente Flos Santorum llaman, Toledo, Iuan Ferrer, 1554; disponible: https://www.digitale-sammlungen.de/de/view/bsb10811748?q=\%28Flos+santorum $\% 29 \&$ page $=314,315$

MAÑAS BALLESTÍN, Fabián, “Pintura gótica en el Campo Romanos. IV. El retablo mayor de la iglesia de Langa del Castillo", Zaragoza, 26 (sept. 1981), pp. 24-26.

MAÑAS BALLESTÍN, Fabián, "Las artes en época medieval", en Comarca del Campo de Daroca, Zaragoza, Departamento de Presidencia y Relaciones, 2003, pp. 139184; disponible: http://institucional.comarcadedaroca.com/sites/default/files/ archivos/Bloque_III._Las_Artes._1._Las_Artes_en_epoca_medieval.pdf

MARINEO SICULO, Lucio, De las cosas memorables de España, Alcalá de Henares, Juan de Brocar, 1539; disponible: https://bvpb.mcu.es/es/consulta/registro. do?id=404344

MATEO GÓMEZ, Isabel, Temas profanos en la escultura gótica española. Las sillerías de coro, Madrid, Instituto Diego Velázquez, 1979.

MATEO GÓMEZ, Isabel, "El artesonado del claustro del monasterio de Silos", en IBÁÑEZ PÉREZ, Alberto Carlos (dir.), Silos. Un milenio. Actas del Congreso Internacional sobre la abadía de Sto. Domingo de Silos, Burgos, Universidad de Burgos-Abadía de Silos, 2003, v. IV, pp. 255-296.

MOREAU, Sébastien, "La Prinse et délivrance du Roy, venue de la Royne, seur aisnée de l'empereur et recouvrement des Enfants de France, 1526-1530", en CIMBER, Louis y DANJOU, Félix, Archives curièuses de l'Histoire de France, $2^{\mathrm{a}}$ serie, T. 1, Paris, Beauveais, 1835, pp. 251-451; disponible: https://numelyo.bmlyon.fr/f_view/BML:BML_00GOO0100137001102919474\#

ORTEGO Y FRÍAS, Teógenes, Ágreda, bastión de Castilla hacia Aragón, Soria, Caja de Ahorros y Préstamos de la Provincia de Soria, 1980.

PEÑA GARCİA, Manuel, Ágreda: Santa María de los Milagros. Libro del peregrino, Soria, Unión Gráfica, 1979.

PÉREZ DE URBEL, fray Justo, El claustro de Silos, Burgos, Institución Fernán González, 1975.

POLANCO MELERO, Carlos, “Un destello arquitectónico del siglo XIV: la capilla de Santa Catalina, antigua sala capitular de la Catedral de Burgos", Ars Bilduma, 11 (2021), pp. 171-193; disponible: https://ojs.ehu.eus/index.php/ars_bilduma/ article/view/22521

POST, Chandler Rathfon, A History of Spanish painting, v. IV, part I, The Hispano-Flemish style in North-Western Spain, Cambridge Mass., Harvard University Press, 
1933, Kraus reprint CO, New York, 1970.

POST, Chandler Rathfon, A History of Spanish painting, v. VII, part II, The Catalan School in the Late Middle Ages, Cambridge, Mass. Harvard University Press, 1938. POST, Chandler Rathfon, A History of Spanish painting, v. VIII, The Aragonese school in the Late Middle Ages, Cambridge, Mass., Harvard University Press, 1941.

POST, Chandler Rathfon, A History of Spanish painting, v. IX, The Beginning of the Renaissance in Castile and Leon, Cambridge, Mass., Harvard University Press, 1947.

REBOLLO GUTIÉRREZ, Carmen, “Maese Nicolás Francés: su obra y estilo, estado de la cuestión" en De Arte: Revista de Historia del Arte, 6 (2007), pp. 107-130; disponible: http://revpubli.unileon.es/ojs/index.php/dearte/article/view/1529

SÁNCHEZ AMEIJEIRAS, Rocío, "History and Stories of Love and Conversion in Fourteenth-Century Burgos", Hispanic Research Journal, 13/5 (2012), pp. 449-467; disponible: https://doi.org/10.1179/1468273712Z.00000000028

SÁNCHEZ TRUJILLANO, María Teresa. “Estudio ambiental de las Tablas de San Millán, indumentaria", en Segundo coloquio sobre Historia de La Rioja, V. III, Logroño, Colegio Universitario de La Rioja, 1986, pp. 73-83; disponible: https:// dialnet.unirioja.es/descarga/articulo/555482.pdf

SIGÜENZA PELARDA, Cristina, "La moda femenina a finales de la Edad Media, espejo de sensibilidad. Costumbres indumentarias de las mujeres a través de las artes plásticas del gótico en La Rioja", Berceo, 147 (2004), pp. 229-252; disponible: https://dialnet.unirioja.es/descarga/articulo/1387377.pdf

SILVA MAROTO, Pilar, Pedro Berruguete, Valladolid, Junta de Castilla y León, Consejería de Educación y Cultura, 1998.

SILVA MAROTO, Pilar (com.), Pedro Berruguete. El primer pintor renacentista de la Corona de Castilla, Valladolid, Junta de Castilla y León, 2003.

TARACENA, Blas y TUDELA, José, Guía artística de Soria y su provincia, Madrid, Eosgraf, 1973, (1 ${ }^{\mathrm{a}}$ ed., Soria, Hera, 1928).

TEIJEIRA PABLOS, María Dolores, "La última escultura gótica. Las obras del siglo XV", en YARZA, Joaquín, HERRÁEZ, María Victoria y BOTO, Gerardo, eds., La Catedral de León en la Edad Media. Actas del Congreso Internacional, León, Universidad de León, 2004, pp. 381-397; disponible: https://buleria.unileon.es/ handle/10612/11133

TEIJEIRA PABLOS, María Dolores y BOURNIORT, Jeanne, "Les stalles du groupe de León. Typologie et programme iconographique dans la sculpture gothique tardive espagnole", Revue de l'art, 114/1 (1996), pp. 57-62; disponible: https:// www.academia.edu/3985787/Les_stalles_du_groupe_de_L\%C3\%A9on_Typologie_et_programme_iconographique_dans_la_sculpture_gothique_tardive_ espagnole

TILLAC, Pablo (Jean Paul), "Survivance du costume ibérique chez les basques actuels". Bulletin de la Societé des Sciences, Lettres, Arts et d'Etudes de Bayonne, s/n (1924), pp. 190-206.

TORMO MONZÓ, Elías, “La pintura aragonesa cuatrocentista”, Boletín de la Sociedad Española de Excursiones, 17/2 (1909), pp. 125-134.

VAQUERO Mercedes, "Materia carolingia y motivos folklóricos en Flores y Blancaflor y el romance de Gerineldos", ALEMANY, Rafael, MARTOS, Josep Lluís y 
MANZARO, Josep Miquel (eds.), Actes del X Congrés Internacional de l'Associació Hispànica de Literatura Medieval, Alicante, Institut Interuniversitari de Filologia Valenciana, 2005, v. III, pp. 1559-1574; disponible: https:/dialnet.unirioja.es/ servlet/libro?codigo $=497884$

VÁZQUEZ DE PARGA, Luis, LACARRA, José María y URÍA RIU, Juan, Las peregrinaciones a Santiago de Compostela, Madrid, Escuela de Estudios Medievales, 1948.

VECELLIO, Cesare, Degli habiti antichi et moderni di diversi parti del mondo, Venecia, Damiano Zenaro, 1590; disponible: https://gallica.bnf.fr/ark:/12148/btv1b8446755d.r=vecellio\%20cesare

VECELLIO, Cesare, Habiti antichi et moderni di tutto il mondo, Venecia, Giovanni Bernardo Sessa, 1598; disponible: https://books.google.it/books?id=3OhVAAAAcAAJ\&pg=PR2\&dq=Habiti+antichi+et+moderni+di+tutto+il+mondo\&hl=it\&sa=X\&ved=0ahUKEwiu6qSUnLnKAhWElCwKHR5TBUMQ6AEIJjAB\#$\mathrm{v}=$ onepage $\& \mathrm{q}=$ Habiti $\% 20$ antichi $\% 20$ et $\% 20$ moderni $\% 20 \mathrm{di} \% 20$ tutto\%20il $\% 20$ mondo\& $\mathrm{f}=$ false

VEGA, fray Luis de la, Historia de la vida y milagros de Santo Domingo de la Calzada, Burgos, Juan Bautista Varesio, 1606; disponible: https://digibug.ugr.es/handle/10481/38717

VEYRIN, Philippe, "A propos du turban corniforme", Boletín de la Real Sociedad Vascongada de los Amigos del País, 6/2 (1950), pp. 151-154.

VICO, Enea, Diversarum Gentium nostrae aetatis habitus, Venecia, 1557; disponible: https://www.rijksmuseum.nl/en/search/objects?set=BI-1933-996\#/BI-1933-996,0

VILLAAMIL Y CASTRO, José, La catedral de Mondoñedo, su historia y descripción, sus pinturas murales, accesorios, mobiliario, bronces y orfebrería, vestiduras y ropas sagradas, Madrid, Manuel Galiano, 1865. Reed. corregida y aumentada, con introducción de YZQUIERDO PERRÍN, Ramón, en Estudios Mindonienses, 25 (2009), pp. 129-175; disponible: https://docs.wixstatic.com/ugd/4dc129_70b707bd9a754c259930affbe6bfaba7.pdf

VILLAAMIL Y CASTRO, José, "Pinturas murales de la catedral de Mondoñedo", Museo Español de Antigüedades, 1 (1872), pp. 219-233; disponible: https://prensahistorica.mcu.es/es/catalogo_imagenes/grupo.do?path=1007638320

VORÁGINE, Santiago de la, La leyenda dorada, Madrid, Alianza, 1982.

YARZA LUACES, Joaquín, "Artes del color en el siglo XV en la catedral de León", en YARZA, Joaquín, HERRÁEZ, María Victoria y BOTO, Gerardo (eds.), La Catedral de León en la Edad Media. Actas del Congreso Internacional, León, Universidad de León, 2004, pp. 399-431; disponible: http://hdl.handle.net/10612/7016

YOUNG, Eric, "A rediscovered painting by Pedro Berruguete and its companion panels", The Art Bulletin, 57/4 (diciembre 1975), pp. 473-475; https://doi. org/10.2307/3049431

ZAPARAÍN YÁÑEZ, María José, "Con otros ojos. La promoción nobiliaria femenina en la ribera burgalesa del Duero. Siglos XVI y XVII", Biblioteca: Estudio e investigación, 28 (2013), pp. 261-298; disponible: https://dialnet.unirioja.es/ejemplar/388281 